\title{
Arenig volcanic and sedimentary strata, central New Brunswick and eastern Maine
}

\author{
W.H. Poole ${ }^{1}$ and Robert B. Neuman ${ }^{2}$ \\ 1. Geological Survey of Canada (Emeritus), 601 Booth Street, Ottawa, ON K1A 0E8 <bipoole@NRCan.gc.ca> \\ 2. United States Geological Survey (Emeritus), Department of Paleobiology, National Museum \\ of Natural History, Smithsonian Institution, Washington, DC 20560-0137
}

Date Received:May 24, 2002 Date Accepted:January 10, 2003

\begin{abstract}
Arenig strata in the Napadogan area of the Miramichi Highlands of west-central New Brunswick are similar to those of the Lunksoos anticlinorial area of eastern Maine. Strata from both areas were deposited in a volcanic back-arc setting upon Cambrian-Tremadoc, deep-water, turbiditic quartzose strata on the northwest-facing Gander margin of Gondwana. Tremadoc southeastward obduction of the Penobscot Arc, formed in the Iapetus Ocean to the northwest of the margin, was followed by local uplift, rift faulting, erosion, and finally by local deposition of late Arenig gravel within the early stages of a subsiding back-arc basin that was related to a younger, northwest-facing, early Arenig-Llanvirn Popelogan Arc lying to the northwest. These strata became overlain by late Arenig marine felsic tuff, sandy and silty tuff and mudstone, coarse textured and many hundreds of metres thick in the Lunksoos area but much finer and only a few metres thick farther from the volcanic centres, in the Napadogan area. During Llanvirn, the strata became covered with deep-water, commonly manganiferous, ferruginous shalechert in a basin shielded from currents carrying coarse detritus. Arenig strata of the Napadogan area probably developed to the southeast of the main rift-volcanism zone that perhaps extended between the Lunksoos and northeastern Miramichi Highlands during the Arenig. Brachiopods of the Celtic paleogeographic assemblage colonized newly formed shelves flanking islands along the zone. Shell beds developed upon fresh layers of ash in a nutrient-rich environment between episodes of volcanism. These Celtic brachiopods developed in cool waters of high southern latitudes off Gondwana, different from those on the Laurentian margin in warm waters of low southern latitudes.
\end{abstract}

\section{RESUMÉ}

Les strates de l'Arénig dans le secteur de Napadogan du massif de Miramichi, dans le centre-ouest du Nouveau-Brunswick, sont semblables à celles du secteur anticlinorial de Lunksoos dans l'Est du Maine. Les strates des deux secteurs se sont déposées dans un cadre arrière-arc volcanique au-dessus de strates abyssales quartzeuses et turbiditiques du Cambrien-Trémadoc sur la marge de Gander orientée vers le nord-ouest du Gondwana. L'obduction en direction sud-est de l'arc de Penobscot, durant le Trémadoc qui s'est formée dans l'océan Japet au nord-ouest de la marge, a été suivie d'un soulèvement local, d'une dislocation d'effondrement, d'une érosion et finalement d'une sédimentation locale de gravier de l'Arénig tardif au cours des premiers stades d'un bassin arrière-arc de subsidence qui était apparenté à un arc plus récent orienté vers le nord-ouest de l'Arénig précoce-Llanvirn de Popelogan situé au nord-ouest. Ces strates ont ensuite été recouvertes de tuf felsique marin de l'Arénig tardif, de mudstone et de tuf sableux et silteux, à texture grossière et de nombreuses centaines de mètres d'épaisseur dans le secteur de Lunksoos, mais beaucoup plus fins et de seulement quelques mètres d'épaisseur à une distance accrue des centres volcaniques, dans le secteur de Napadogan. Au cours du Llanvirn, les strates sont devenues couvertes de schiste-silexite ferrugineux, communément manganésifères, abyssaux dans un bassin abrité des courants transportant des détritus grossiers. Les strates de l'Arénig du secteur de Napadogan se sont probablement constituées au sud-est de la zone principale d'effondrement-volcanisme qui s'étendait possiblement entre Lunksoos et le nord-est du massif de Miramichi au cours de l'Arénig. Des brachiopodes de l'assemblage paléogéographique celtique ont colonisé les nouvelles îles riveraines continentales apparues le long de la zone. Des bancs de coquillages se sont constitués sur les couches fraîches de cendre dans un environnement riche en éléments nutritifs entre les divers épisodes d'activité volcanique. Ces brachiopodes celtiques se sont établis dans les eaux tempérées des hautes latitudes méridionales au large du Gondwana, contrairement à ceux de la marge laurentienne présents dans les eaux chaudes des basses latitudes méridionales.

\section{INTRODUCTION}

Continuing investigation of the polydeformed Cambrian and Ordovician rocks of the Miramichi Highlands in west-central New Brunswick has led to an improved understanding of the stratigraphy of the Cambro-Lower Ordovician Miramichi Group and overlying Ordovician Tetagouche Group (van Staal and Fyffe 1991, 1995a, 1995b). Shelly fossils, mainly brachiopods of late Arenig age, have been found in sandy tuff, sandstone, siltstone and mudstone at several places within the basal beds of the Tetagouche Group. In northwestern Napadogan area, the tuff is underlain by oligomictic conglomerate whose quartzite clasts were derived from the Miramichi Group. These basal Tetagouche strata occur within the transition from a deep-water fan complex of quartzose psammitic and pelitic turbidites of the Miramichi Group (Rice and van Staal 1992) and deposition of the overlying volcanic-chertgreywacke assemblage of the Ordovician Tetagouche Group, a transition representing the change from a stable continental margin to an unstable volcanic back-arc setting marked by rifting, local uplift and erosion, followed by mainly felsic volcanism and subsidence. In the northeastern Miramichi Highlands, these Lower-Middle Ordovician strata host the volcanogenic massive, 
base-metal sulphide deposits of the Bathurst mining camp (van Staal et al. 1992; van Staal et al. in press). Mineral exploration companies searched the Napadogan area for similar sulphide deposits and for granophile Sn-W-Mo deposits mainly during the 1970s and 1980s. No deposits justifying development were found and exploration has since decreased. Perhaps the work reported here will help guide future exploration to more prospective formations. The geology of the Napadogan area is not known in as great a detail as is the Bathurst camp. The results reported here may be a first step to improved comparisons and integration of the stratigraphy and depositional and tectonic settings of the rocks of the two areas.

Early surveys of the bedrock geology of the Napadogan area of central New Brunswick outlined a broad belt roughly 40 kilometres wide, of deformed and cleaved sedimentary rocks, lying between the granitic plutons on the northwest and the flat-lying Carboniferous cover of central and eastern New Brunswick (Robb 1870; Ells 1881). Robb collected brachiopods at one locality (herein, the Rocky Brook locality) within this extensive unfossiliferous area and they were interpreted as Silurian-Devonian of the Gaspé Limestone series (Billings in Robb 1870, p. 190). These fossiliferous rocks were "accommodated" on a regional geological map as a "patch" of young strata of unknown relations to the presumed Cambro-Silurian rocks (i.e. Ordovician in later years; Bailey et al. 1886). Later, similar brachiopods were found $25 \mathrm{~km}$ on trend to the northeast by Ells (1881) (herein, the Lower Birch Island locality); the fossils were collected by Bailey (1906) and interpreted as Silurian by Ami (1906).

Fifty years later, regional bedrock geological mapping by the Geological Survey of Canada for publication at one mile to an inch (Poole 1958, 1960, 1963; Anderson and Poole 1959) divided the 40-kilometre belt in two: a Cambrian-Ordovician belt (the Miramichi terrane) and to its southeast, a belt of Silurian turbidites with a few graptolite localities (the Fredericton Trough). The brachiopods of the two early-found localities and a new locality (herein, the Middle Hayden Brook locality) were firstly reinterpreted as Ordovician and later by Neuman as probably late Arenig when compared to his collections from the rich localities of eastern Maine in the Weeksboro-Lunksoos area and of Newfoundland and Europe (Neuman and Bates 1978; Neuman and Harper 1992), coupled with precise $\mathrm{U}-\mathrm{Pb}$ zircon isotopic ages from related volcanic rocks in the northeastern Miramichi Highlands. [For simplicity, we will use "Napadogan area" to refer to the area of interest in the Napadogan-Hayesville area of central New Brunswick, and to "Lunksoos area" for the Weeksboro-Lunksoos anticlinorial area of Maine, the latter following the lead of Boone and Boudette (1989, p. 29)].

During the late 1970s and early 1980s, Irrinki $(1980,1981)$ and Crouse (1981a, 1981b) of the New Brunswick Department of Natural Resources, remapped and refined the bedrock geology of mainly the Miramichi terrane of the Napadogan and Hayesville map areas $(21 \mathrm{~J} / 07,10)$. And finally, during the late 1990s, 2000 and 2002, Poole mapped selected localities of Ordovician strata in detail mainly along roads built for logging activities during the past 20 years.

In hilly, forested central New Brunswick, bedrock exposures are

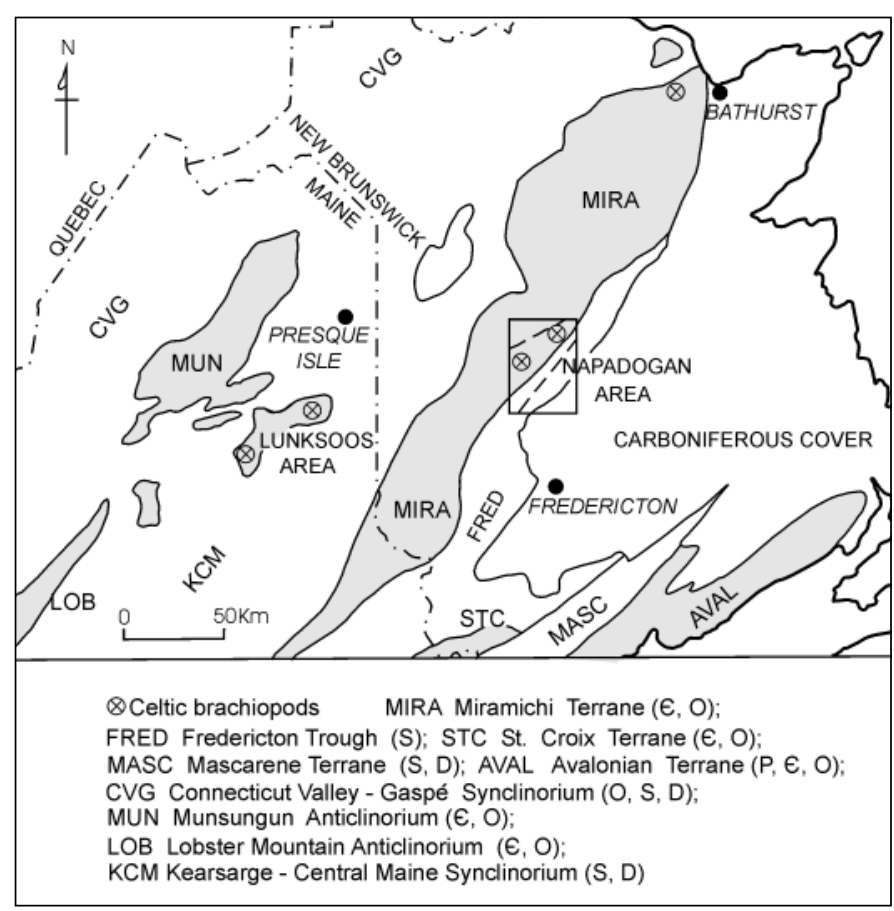

FIG. 1 Anticlinoria of the Napadogan and Lunksoos areas of New Brunswick and Maine, showing Celtic assemblage brachiopod localities. Pre-Silurian rocks shaded. After Fyffe and Fricker (1987) and Boone and Boudette (1989).

sparse and generally small and of poor quality. Bedrock is exposed mainly along streams and roads cut through a blanket of glacial till ranging in thickness from a half metre or less on some hilltops to one or two metres along flanks of most hills and several metres in broad valley bottoms. Exposures along logging roads generally provide only lithology from weathered rocks and some bedding and cleavage measurements. Rarely are key stratigraphic and structural relations helpfully displayed on cliffs. Distribution of bedrock units beneath thin till is suggested by a rubble of bedrock broken by road-building bulldozers.

Herein, we describe the Arenig strata in the Napadogan and Lunksoos areas and compare them to strata in the northeastern Miramichi Highlands (Fig. 1) to demonstrate some similarities and differences. We will introduce new formation and member names for Arenig strata in the Napadogan area, suggest interpretations of their modes of deposition and then discuss the brachiopods from new localities discovered in the Napadogan area during recent years.

For divisions of Ordovician time, we use the British series Tremadoc, Arenig, Llanvirn (including Llandeilo stage), Caradoc and Ashgill (Fortey et al. 1995). The time scale of McKerrow and $\operatorname{van}$ Staal (2000) is used as a modern, reasonable approximation.

The northern two thirds of the Napadogan area (the "Freehold") is currently owned and logged by Bowater Canadian Forest Products Inc., Boiestown, New Brunswick. Access to the logging road system leading north from the southern boundary, for day trips only, is controlled by gatekeepers at Napadogan, Gordon Vale and McKiel Brook. 
Within some figure captions, GSC Photo xx refers to the photograph collection of the Geological Survey of Canada, and GSC loc. xx refers to the locality of a fossil collection registered with the Geological Survey of Canada. The illustrated fossil specimens of Fig. 11 are in the National Type Collection, Geological Survey of Canada, Ottawa.

\section{REGIONAL TECTONIC SETTING}

The current model of the regional tectonic setting of the rocks of Napadogan and Lunksoos areas has been developed by many geologists working in northern New Brunswick and northern Maine during the past twenty years or more. Of course, unanimity has not been achieved. From the view of the Miramichi terrane, syntheses by van Staal et al. (1992), van Staal et al. (1998) and van Staal et al. (in press) list co-authors who have contributed to the model. The view developed from Maine's geology has been summarized by such authors as Boone and Boudette (1989), Boone et al. (1989) and Berry and Osberg (1989). All these syntheses contain extensive reference lists.

Rocks of the Napadogan and Lunksoos areas are linked to two volcanic arcs that lay to the northwest (today's directions; van Staal et al. 1998; van Staal et al. in press). The arc strata are well exposed in Newfoundland but unfortunately are mainly covered in northern New Brunswick although they are somewhat better exposed in northern Maine. According to the above authors, the older, ensimatic Penobscot Arc existed within Iapetus Ocean above a northwest-dipping subduction zone during at least Middle Cambrian to Tremadoc. Tremadoc-early Arenig collision with the northwest-subducting Gander margin (Ganderia; van Staal et al. 2002a) with its cover of Miramichi strata (periGondwana) led to obduction of the arc perhaps as many as hundreds of kilometres to the southeast. At least parts of the outer edge of the Gander margin were then uplifted and rifted, and the obducted Penobscot Arc rocks largely removed by erosion. Possible remnants of the arc rocks are bimodal, within-plate and possibly subduction-related volcanic rocks in the Annidale Group and subduction-related volcanic rocks of the New River Belt, both of southern New Brunswick (McLeod et al. 1994; Johnson and McLeod 1996), and of coastal Maine, bimodal, within-plate continental rift volcanic rocks of the Ellsworth Schist (Stewart et al. 1995). However, all these formations occur within zones of northeast-striking thrusts and strike faults near and within the complex zones between the Gander margin, Brookville terrane and northwestern parts of the composite Avalonian terrane that could well have involved volcanic arcs and nearby back arcs (Barr and White 1996). Indeed, no exposed remnant of the Penobscot Arc may exist in New Brunswick and Maine, but samples may exist as clasts and heavy minerals in Arenig conglomerates. A search for the tectonic setting of the source volcanic rocks and indicator minerals such as chromite has not been conducted.

The younger, Popelogan volcanic arc started about early to middle Arenig after obduction of the Penobscot Arc was completed (van Staal et al. 1998; van Staal et al. in press). The subduction zone changed from northwest-dipping during Penobscot time to southeast-dipping during Popelogan time. Oldest rocks assigned to the Popelogan Arc are volcanic rocks of the Meductic Group within the Miramichi terrane about $80 \mathrm{~km}$ southwest of the Napadogan area (Fyffe 2001). The volcanic rocks grade broadly from rhyolite stratigraphically upward to basalt and intruded arc-setting granite, all of early to middle Arenig age, and include intercalated green and maroon manganiferous chert and slate. The group lies conformably upon black slate and siltstone of the Bright Eye Brook Formation containing late Tremadoc to earliest Arenig graptolites (Fyffe et al. 1983; Pickerill and Fyffe 1999). The geochemistry of the volcanic rocks suggests a change from base to top from a compressional-continental arc setting to an extensional-continental arc setting (Fyffe 2001). Arc volcanism ceased when the subduction zone migrated northwestward as the extensional Tetagouche back-arc basin opened on the Gander margin (including the Napadogan and Lunksoos areas). Today, Lunksoos rocks lie $40 \mathrm{~km}$ to the northwest of southern Miramichi terrane and the two areas are separated by mainly Siluro-Devonian strata (Fig. 1). Lunksoos bimodal volcanic and sedimentary rocks of the mainly late Arenig Shin Brook Formation unconformably overlie slate and turbiditic quartzite of the Grand Pitch Formation, the oldest rocks exposed. The geochemistry of a few of the volcanic rocks suggests that they lie above a sialic crust probably in a back-arc setting like that of northern New Brunswick (Winchester and van Staal 1994) and probably like that of the Napadogan block (van Staal et al. in press). If the age assignments are correct, the timing of Meductic arc volcanism overlapped with a period of rifting, uplift and erosion of Miramichi-Grand Pitch rocks in the back arc, and early to middle Arenig volcanic rocks were not deposited in the back arc in the Napadogan area. The Popelogan Arc rocks that are exposed in the Popelogan inlier of northeastern New Brunswick consist mainly of Llanvirn andesitic to basaltic arc rocks and early Caradoc black shales (van Staal and Fyffe 1991). The volcanic rocks were produced when the subduction zone migrated to the northwest due to rollback of the southeastward subducting slab (van Staal et al. 1991). The Meductic and Popelogan-inlier rocks developed to the northwest of the Napadogan and Lunksoos areas. During the late Caradoc and Ashgill, the Popelogan Arc was uplifted, obducted toward the northwest and amalgamated with the Boundary Mountains terrane of northern Maine. The uplifted arc rocks shed detritus that was carried in turbidity currents toward the southeast upon the Gander margin (van Staal et al. 1998; van Staal et al. in press). The rocks of the Napadogan and Lunksoos areas are a sample of this back-arc basin.

In contrast, another interpretation developed by Boone et al. (1989) and Boone and Boudette (1989), largely in northern Maine, involves only one subduction zone between the Boundary Mountain terrane and the Gander margin. The Hurricane Mountain Formation of mainly Middle and Upper Cambrian strata, containing polymictic tectonic mélange with olistostromes, is interpreted as an accretionary wedge related to a subduction zone lying south of the Boundary Mountains terrane and dipping southeast beneath the Gander margin. The Boundary Mountains terrane moved southeastward and became amalgamated with the Gander margin during Late Cambrian to Early Ordovician, the Penobscottian (Penobscot) orogeny. Taconian deformation later 
during the Ordovician consisted of warping and local open folding and high-angle faulting. Volcanic arc rocks related to the subduction zone were not identified with confirming geochemistry. An amalgamated Boundary Mountain-Gander terrane would have permitted Celtic brachiopods to occupy the Boundary Mountains segment; none have been reported there. It seems more probable that an ocean existed between the two terranes during the Arenig at least. Thus, we prefer the Penobscot-Popelogan model of van Staal and colleagues as described above.

\section{MIRAMICHI GROUP OF THE NAPADOGAN AREA}

The oldest rocks in the Napadogan area are deep-water, turbiditic, interbedded slate and quartzite of the Miramichi Group, deposited during the Cambrian and Tremadoc on the continental slope along the northwest side of the Gander margin bordering the Iapetus ocean (Rice and van Staal 1992; van Staal et al. in press). Light grey to greenish grey slate and quartzite with some laminated siltstone occur throughout the Napadogan area. Thin section study of several specimens reveals a subgreywacke mix of quartz, plagioclase and matrix. Quartz grains are generally subangular, 0.2 to $0.3 \mathrm{~mm}$ in diameter (fine- to medium-grained sand) with "outsize" subrounded grains to $0.7 \mathrm{~mm}$ (coarse-grained sand) with $6 \%$ to $16 \%$ plagioclase presumably albite, $10 \%$ to $25 \%$ matrix of fine-grained secondary micas and metamorphic albite(?) and traces of detrital muscovite, tourmaline (pleochroic colourless to green to brown - schorlite?) and zircon (petrography and point counts by Fred Harris 1961-62). The quartzite has characteristics of a turbidite, and certainly not those of a mature, quartz beach sand. Only along the northwestern side of the Napadogan area (Otter Slide belt, Fig. 2) does the top unit of the group include black slate with minor dark grey quartzite and dark grey greywacke containing exotic felsic volcanic detritus (vitreous black quartz and bluish quartz grains) deposited in anoxic deep water. Whether the black slate-quartzite-greywacke facies was deposited only in the strata of the northwestern belt or was deposited throughout the Napadogan area and was removed by erosion during the Tremadoc-Arenig is conjectural. We favour the former alternative for reasons presented later in the paper. Further, perhaps the dark grey slate unit was deposited in anoxic deep water while to the southeast, higher on the continental slope, a light grey slate facies was deposited in oxic water depths. The dark facies, which includes one low outcrop on Turnbull Mountain of medium to dark grey fine pebble conglomerate consisting of pebbles of medium to dark grey quartzite, 1 to $4 \mathrm{~cm}$ in diameter, in a dark grey pelitic matrix, probably signalled deepening water as the Gander margin closed on the Penobscot Arc just prior to Penobscot obduction during the Tremadoc-early Arenig (Fyffe et al. 1983; van Staal et al. in press). The dark grey slate and light grey slate facies are grossly interlayered. Perhaps the dark grey slate facies with its volcanic detritus was derived from the deforming Penobscot volcanic arc to the northwest while the light grey slate facies was derived from the Gander margin to the southeast. Thus the two facies became interlayered in a trough between deforming arc and approaching margin in waters near oxic-anoxic depths.
Today, the Miramichi rocks core anticlinorial belts with infolded and infaulted Ordovician strata, and many are surrounded by Siluro-Devonian strata (Fig. 1). These old rocks, the oldest known within the Miramichi terrane, were intruded by syn-volcanic Ordovician granites (north of the Napadogan area) and were metamorphosed, deformed, probably thrust southeastward, and intruded during post-mid-Ordovician deformations. The three belts of Miramichi strata in the Napadogan area are referred to as the Lower Hayden, Burnt Hill and Otter Slide belts for easy geographic reference (Fig. 2).

\section{TETAGOUCHE GROUP OF THE NAPADOGAN AREA}

Overlying the Miramichi Group in the Napadogan area with presumed local unconformity in the northwest but conformity or disconformity in the southeast is the Arenig-Ashgill Tetagouche Group, a varied sedimentary-volcanic assemblage representing the product of a volcanic back arc and subsequent infilling, developed upon the Miramichi basement cover of the Gander margin (van Staal 1994; van Staal and Fyffe 1995a). Early Arenig uplift along the northwest part of the margin in the Napadogan area was characterized by some tilting and warping without folding, presumably along rift faults; one associated uplift, herein referred to as the Napadogan uplift, exposed Miramichi Group strata to erosion. Van Staal et al. (1991) attributed the uplift and disconformity at the base of the Tetagouche Group (Vallée Lourdes Member) and subsequent volcanism in the northeastern Miramichi terrane to lithospheric doming associated with arc rifting and with rollback of the subducting slab. In the Napadogan area, a coarse gravel of Miramichi quartz sandstone was deposited there and along the northwest-facing Iapetan margin and then probably slumped into deeper water (Upper Buttermilk Member of the Turnbull Mountain Formation - new names). Soon after, late Arenig felsic volcanism from distant sources deposited several metres of sandy and silty tuff, and minor crystal tuff along with mudstone in some localities, followed by minor local mafic tuff and flows (Lower Birch Island Member of Turnbull Mountain Formation). The volcanic deposits became overlain by a blanket of Llanvirn ferruginous and manganiferous, varicoloured slate and chert and during Caradoc, the waters became anoxic (deeper?) and the slate and chert carbon-rich and pyritic. Finally, during the late Caradoc and Ashgill, turbidity currents began to fill the basin with dark grey mudstone and volcanic greywacke derived from an uplifted and deforming Popelogan Arc to the north (van Staal 1994). Ten to 30 kilometres to the north and northeast of the Napadogan area of this paper, felsic and mafic volcanic rocks are more abundant (Poole 1963; Irrinki 1980, 1981), and some mafic volcanic rocks contain blocks of Llanvirnian slate and chert.

\section{Turnbull Mountain Formation}

The Arenig conglomerate and late Arenig bimodal volcanic rocks and sedimentary rocks are collectively herein named the Turnbull Mountain Formation, comprising two subunits, the 


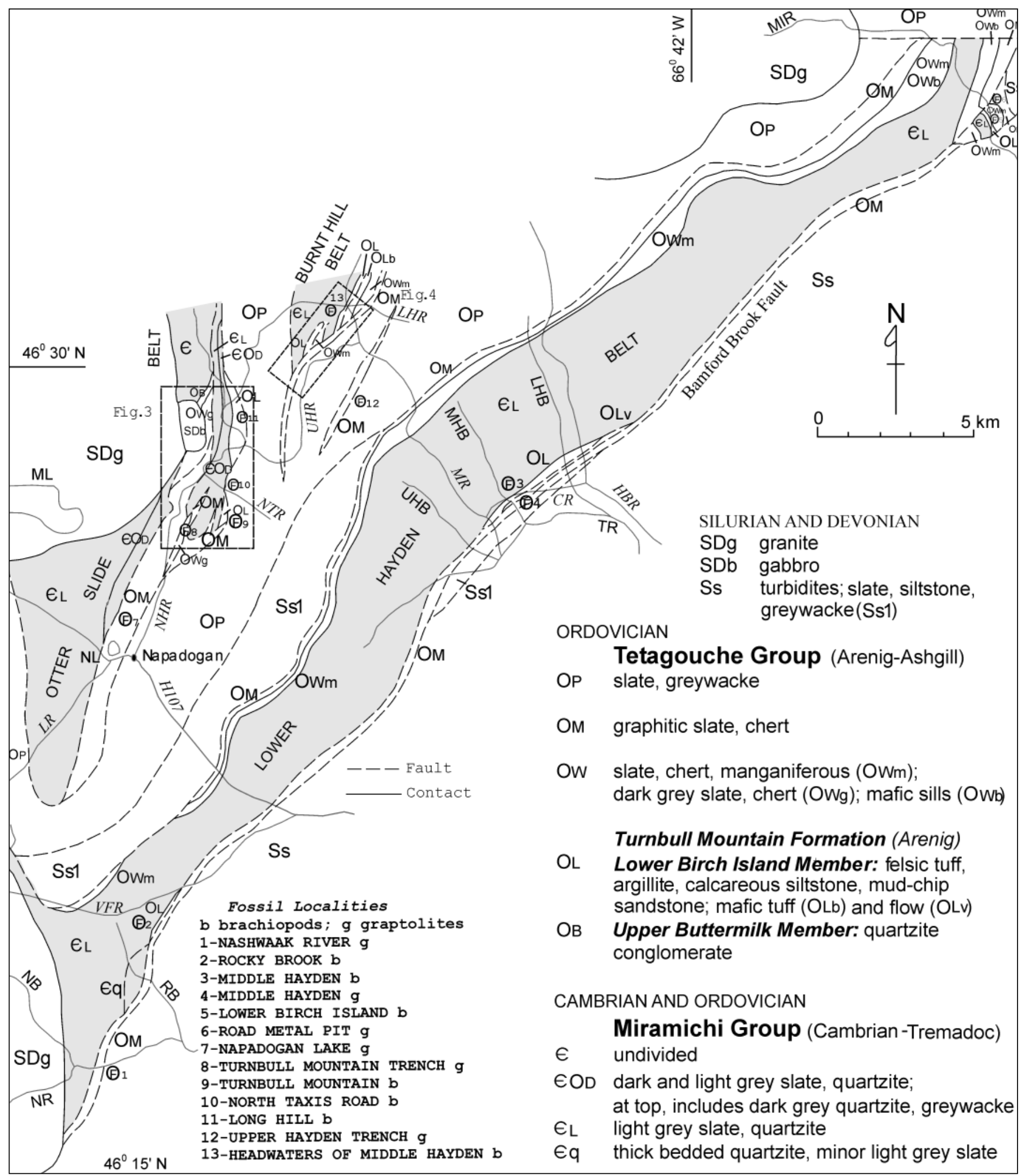

FIG. 2 Geology of Cambrian and Ordovician units of the Napadogan area, with shaded Miramichi Group in the Lower Hayden, Burnt Hill and Otter Slide belts. Geology after Poole (1963) modified by recent unpublished mapping by Poole. Circled F = fossil locality keyed by number to the list of brachiopod and graptolite localities. Locations of Figs. 3 and 4 outlined. Streams and lakes: NR Nashwaak River, NB Napadogan Brook, RB Rocky Brook, TR Taxis River, UHB Upper Hayden Brook, MHB Middle Hayden Brook, LHB Lower Hayden Brook, MIR S.W. Miramichi River, NL Napadogan Lake, ML Miramichi Lake. Roads: VFR Valley Forest road, LR Lake road, H107 Highway 107, NHR Napadogan haulage road, NTR North Taxis road, UHR Upper Hayden road, LHR Lower Hayden road, MR Mine road, CR Cross road, HBR Hovey Brook road. 
basal Upper Buttermilk Member of quartzite conglomerate and the overlying Lower Birch Island Member of felsic tuff and minor mafic tuff and flows, and sandstone varying to siltstone and slate. The younger member has yielded brachiopods in seven localities. The formation is named from Turnbull Mountain on which the two members are exposed, $5 \mathrm{~km}$ north-northeast of the small community of Napadogan (Fig. 2). All geographic names of new formations are recognized by the Geographic Names Board of Canada.

Exposures of Turnbull Mountain strata have been found only there and above Miramichi Group strata and below the overlying Llanvirn slate-chert unit of the Tetagouche Group. No exposure displays strata of both members from base to top. Thus, an ideal type section cannot be identified. Currently, a type area enclosing several localities as depicted in the Napadogan area of Fig. 2 must serve. The overall stratigraphic sequence has been established by integrating parts of the stratigraphy from these localities. This lack of continuity is attributed to a combination of unrelated factors such as discontinuous deposition (especially of the Upper Buttermilk conglomerate), thrust and strike-slip faulting during subsequent deformation, and generally sparse exposures. It is impossible to determine with confidence, in any one locality, which cause or combination of causes explains the presence or absence of units.

The Turnbull Mountain Formation overlies the Cambrian and Tremadoc Miramichi Group and is overlain conformably by Llanvirn slate-chert. The formation is no more than $10 \mathrm{~m}$ thick at its thickest in the northwestern Napadogan area. It is probably middle to late Arenig, an age derived from brachiopods and conodonts in the upper member and, from the northeastern Miramichi terrane U-Pb zircon isotopic ages of correlative volcanic rocks. Correlative formations are the Shin Brook Formation in the Lunksoos area and Nepisiguit Falls Formation in the northeastern Miramichi Highlands with its basal sedimentary Vallée Lourdes Member and overlying volcanic Little Falls Member (van Staal et al. in press).

\section{Upper Buttermilk Member}

The Buttermilk Brook Formation was first named by Potter (1969) in his unpublished Ph.D. thesis on the geology of the Burnt Hill area (in the Burnt Hill belt of this paper), a few kilometres north of the northern edge of the Napadogan area. The name was derived from a small brook known by local people as Upper Buttermilk Brook in the 1960s, but not then recognized by the Geographic Names Board of Canada. Another brook, $5 \mathrm{~km}$ to the northeast was recognized by the Board as Buttermilk Brook, where the formation apparently does not exist. Currently, the names of both brooks are recognized by the Board. Irrinki (1981) applied the name Buttermilk Brook to a small granite stock exposed along Buttermilk Brook. Potter's name was later used in regional syntheses, for example, by van Staal and Fyffe (1991, 1995a).

The name 'Upper Buttermilk Member' (of the Turnbull Mountain Formation) is herein proposed to replace Buttermilk Brook Formation of Potter (1969). The new name recognizes the nearby Upper Buttermilk Brook and avoids confusion with the
Buttermilk Brook granite of Irrinki (1981). The term "brook" is omitted in accordance with recommendations of the North American Code of Stratigraphic Nomenclature and, more practically, to keep the name reasonably short.

Potter's type area is on the northwest side of a ridge, the north end of which is $2 \mathrm{~km}$ south of the former Burnt Hill mine and 4 $\mathrm{km}$ northeast of the Napadogan area, within the Burnt Hill belt (Fig. 2). Along $2 \mathrm{~km}$ of the ridge to the southwest, sporadic metresize blocks of conglomerate attest to their nearby bedrock source. However, at the north end of the ridge is a large area of outcrop and slumped blocks on a short bluff and steep slope, unseen by Potter (1969) but mapped by Crouse (1981a). The site is on the northwest corner of the ridge, about $300 \mathrm{~m}$ south of an unnamed branch of the Upper Buttermilk Brook that limits the ridge on the north. Despite that rocks stratigraphically above and below the conglomerate are not exposed near this outcrop, this locality is here designated the type locality. Unfortunately, access is difficult; the nearest road suitable for motor vehicles is the Mine road, one kilometre of bush and forest to the west.

Potter described the unit, speculatively about $250 \mathrm{~m}$ thick, as a lower part of grey-green conglomerate with subangular to subrounded pebbles (some larger than $4 \mathrm{~cm}$ ) of quartz sandstone $(\leq 35 \%)$, siltstone $(30 \%)$ and laminated quartz siltstone $(<5 \%)$, and an upper part of poorly sorted distinctively grey-green sandstone and siltstone. Crouse (1981a), in the same area, described the conglomerate as comprising angular to subrounded pebbles of siltstone, quartzose sandstone and quartz wacke in a sparse phyllitic matrix; pebbles are commonly 3 to $5 \mathrm{~cm}$ in diameter to a maximum of $25 \mathrm{~cm}$. He observed that the conglomerate is interbedded with light greenish grey siltstone. Current geological mapping by Poole in the Napadogan area and in the Burnt Hill belt has demonstrated that the conglomerate is probably no more than several metres thick in most if not all localities, and consequently the unit is designated as a member in this paper. Further, Poole did not observe the siltstone interbeds of Crouse, and the grey-green sandstone and siltstone of Potter is assigned to the upper part of the Lower Birch Island Member.

In the Napadogan area, the Upper Buttermilk Member consists of conglomerate that presumably rests sharply on Miramichi strata (the basal contact has not been seen in the Napadogan area or anywhere in central New Brunswick) and is from zero to perhaps several metres thick (Figs. 2, 3, 4). One exposure east of Turnbull Mountain is $7 \mathrm{~m}$ wide across structural trend but bedding is not visible. The conglomerate consists of a light grey to green-grey, clast-supported pebble and cobble quartzite, which range from granules to a maximum of $25 \mathrm{~cm}$ in diameter, in a minor sandy matrix (Fig. 5). The clasts are well rounded to subrounded, oblong to spherical, or slightly flattened by imposed deformation, and they are clearly derived from the underlying Miramichi Group. Absent are clasts of greywacke, feldspathic quartzite, medium to dark grey quartzite and black mudstone, all characteristic of the uppermost strata of the Miramichi Group in the northwesternmost Napadogan area. Absent are any exotic rocks such as chert, granite and volcanic and metamorphic rocks. Another notable absence are pebbles of vein quartz and of quartzite clasts containing quartz veins before erosion and deposition. Thus, evidence of 


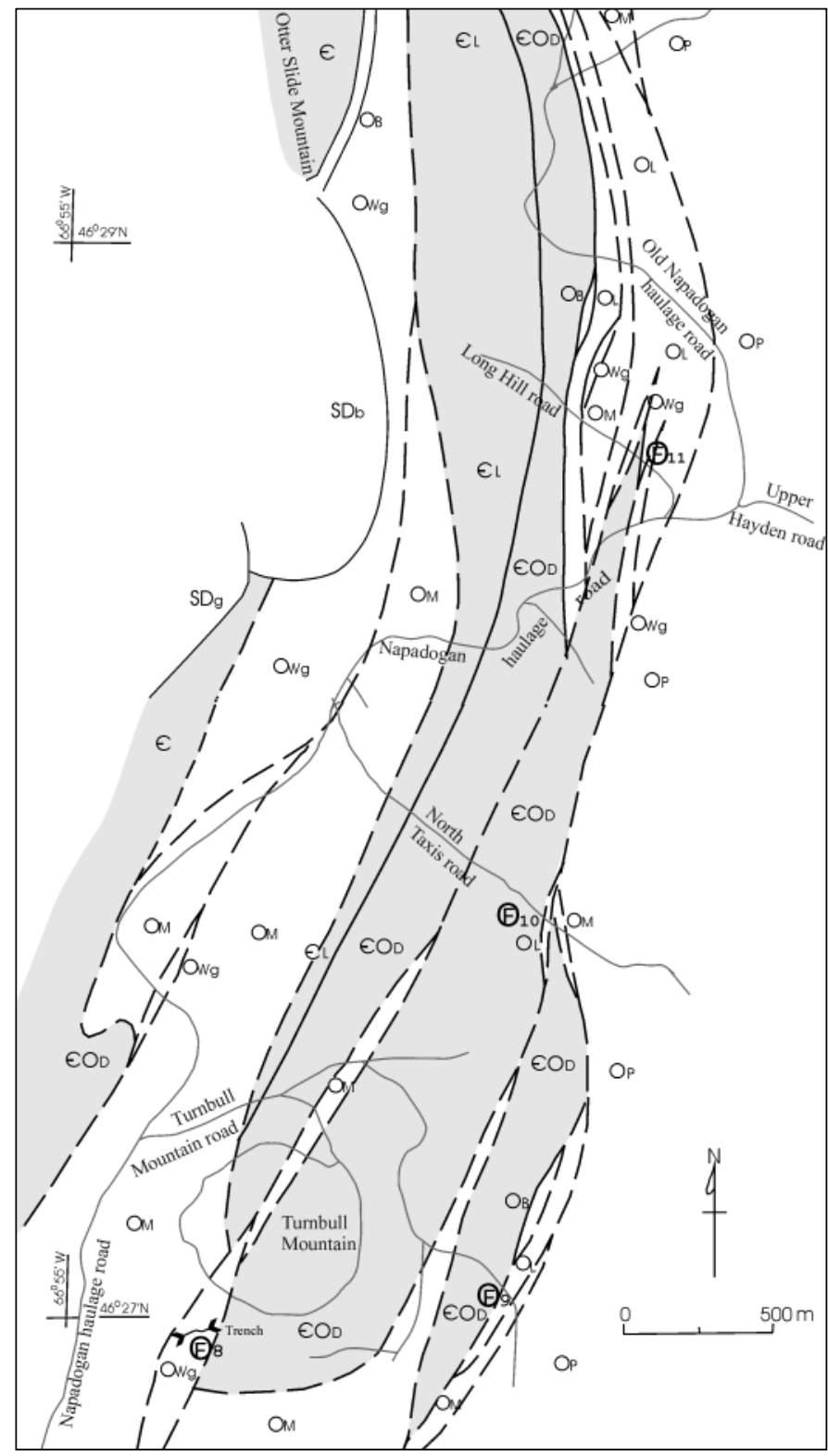

FIG. 3 Details of geology of the Turnbull Mountain-Otter Slide Mountain area of the Otter Slide belt, illustrating the fault-sliced style of probable eastward thrusts of the Miramichi Group (shaded) over slate and greywacke (OP). Geology by Poole, unpublished. Location outlined on Fig. 2. Circled $F=$ fossil localities keyed by number to list on Fig. 2. Legend as on Fig. 2.

penetrative deformation and concomitant quartz-vein generation at the level of erosion in the source area before or during uplift is lacking.

The conglomerate occurs sporadically within the Otter Slide and Burnt Hill belts. It is absent in the Lower Hayden belt where the younger Lower Birch Island Member rests conformably upon Miramichi light grey slate and quartzite at the Lower Birch Island brachiopod locality and almost assuredly elsewhere along the belt. The conglomerate is notably massive and lacks bedding and interbeds as viewed close to the outcrop. The conglomerate was probably derived from a gravel that accumulated on fans off

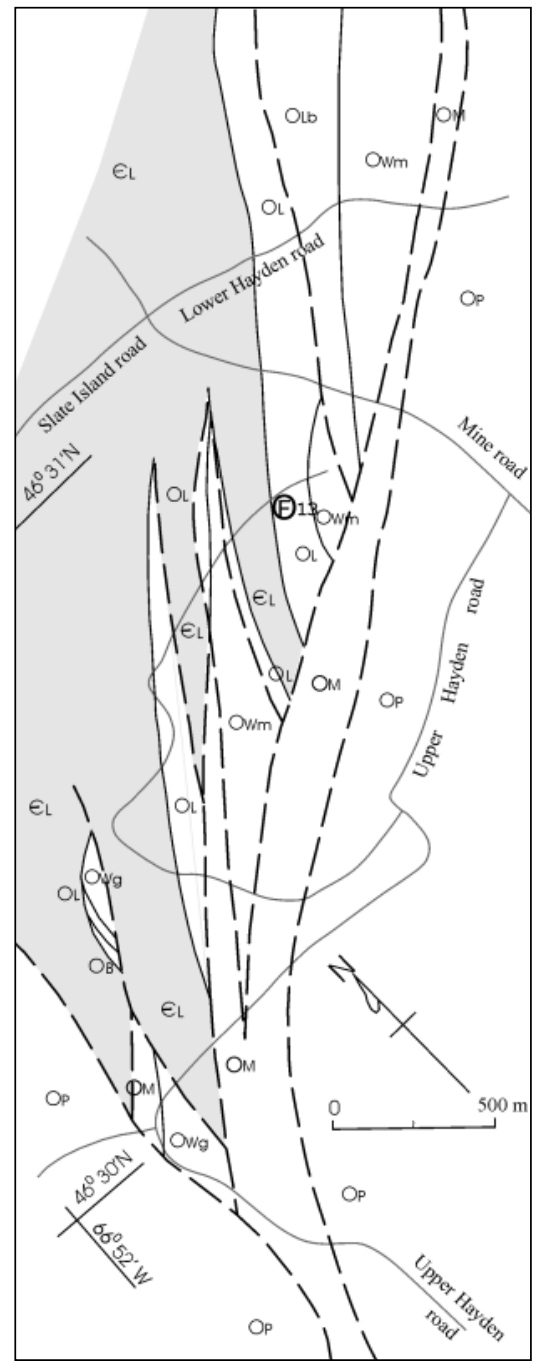

FIG. 4 Details of geology of the Upper Hayden-Mine roads area of the Burnt Hill belt, illustrating the fault-sliced style of the southwest termination of the Miramichi Group belt (shaded) that was probably thrust southeastward over slate and greywacke (OP). Geology by Poole, unpublished. Circled F = single brachiopod locality keyed to Fig. 2. Legend as on Fig. 2.

the mouths of streams cutting through a rift-fault scarp exposing only the upper part of the Miramichi light grey mudstone and lithified quartz sandstone. The lack of mudstone clasts in the conglomerate attests to their weak lithification and vigorous stream transport. The gravel was probably resedimented by flowing en masse to the northwest down submarine canyons that cut through the outer edge of the rifted uplift (the Napadogan uplift) into a continental slope-type environment, like that described by Hubert et al. (1970) for the emplacement of limestone conglomerates in the Cambrian-Ordovician Québec Group along the lower St. Lawrence River. In the Otter Slide belt, the gravel came to rest 


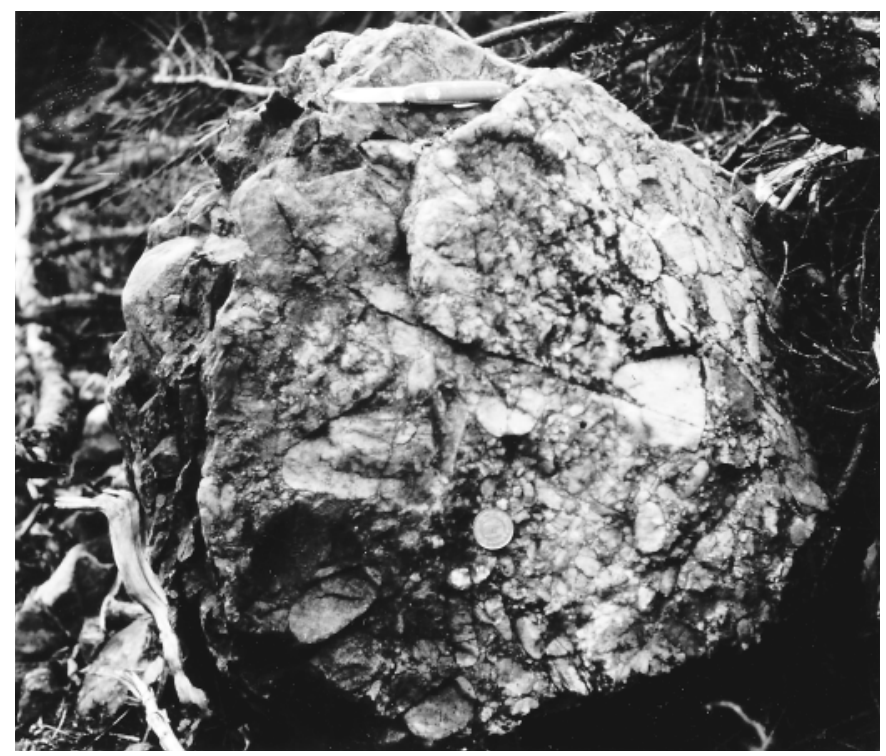

FIG. 5 Block of quartzite conglomerate from nearby bedrock source, Otter Slide belt. Round to subround quartzite pebbles, clast-supported, in minor quartz sandy matrix. Upper Buttermilk Member of the Turnbull Mountain Formation. Arenig. Open penknife is $13 \mathrm{~cm}$ long. Location $0.7 \mathrm{~km}$ northwest of junction of Napadogan haulage road and Upper Hayden road (see Fig. 3). GSC Photo 2001-383B

upon the anoxic (deep water?), dark grey mudstone, sandstone and wacke strata at the top of the Miramichi Group and in the Burnt Hill belt, upon the less deep, light grey mudstone and sandstone unit. Furthermore, it seems that the rift faults accompanying the uplift probably occurred in a relatively narrow belt of the light grey slate facies. The conglomerate formed a series of fans, now appearing as lenses, that thin and pinch out along strike. The basal contact of the conglomerate probably displays a sharp contact, disruption of the immediately underlying beds and incorporation of fragments of the underlying beds in the basal part of the conglomerate. This model is preferred to one that involves widespread uplift of the Gander margin and removal by erosion of the uppermost strata of the Miramichi Group (plus any or most obducted Penobscot Arc rocks). In the northeastern Miramichi Highlands, van Staal et al. (in press) favour a disconformity at the base of the Tetagouche Group that represents "significant local erosion" to explain "large variations in thickness and local absence" of the uppermost formation of the Miramichi Group throughout the Bathurst area (van Staal et al. 2002b).

\section{Correlation of Upper Buttermilk Member}

In the Lunksoos area, the Shin Brook Formation consists mainly of felsic volcanic rocks and their sedimentary equivalents, but at one locality southeast of Roberts Mountain, the basal $3 \mathrm{~m}$ of the formation is quartzite conglomerate with round quartzite clasts as large as $25 \mathrm{~cm}$ in diameter (Neuman 1964,1967). The conglomerate appears to be lithologically identical to the conglomerate in the
Napadogan area (judging from one large specimen provided by Gary M. Boone, 2000) and may well have been formed in the same manner. However, several kilometres along strike to the northeast in the Island Falls quadrangle, a lens of conglomerate, basal to the Shin Brook Formation and as thick as 30 metres, consists of pebbles of felsite, quartzite and slate in a chlorite-rich sandstone matrix (Ekren and Frischknecht 1967). Locally, the conglomerate contains "boulder-size fragments of diverse volcanic rocks and quartzite" (p. 5). If indeed the conglomerate of the Shin Pond and Island Falls quadrangles are equivalent in stratigraphic position and age, they demonstrate a great variation in source rocks in rather close-by localities. The source of volcanic rocks must have been nearby but these "phantom" volcanic rocks have not been recognized. The crystal tuff reported in the Grand Pitch Formation of the Shin Pond quadrangle along Seboeis River (Neuman 1967, p. 6) has been reinterpreted as a non-volcanic sediment by Neuman. E.B. Ekren (written communication 2002) confirms that the polymictic conglomerate lies stratigraphically at the base of the Shin Brook Formation. An interpretation must accommodate the areal variation of clast lithology.

In the northeastern Miramichi Highlands along the "upper" Tetagouche River, the basal bed of the Vallée Lourdes Member in the Little Falls section is a fine-grained pebble conglomerate, $0.5 \mathrm{~m}$ thick, consisting of $90 \%$ pebbles ( $1-2 \mathrm{~cm}$ in diameter) in a quartzcalcite matrix, that rests sharply on the Patrick Brook Formation (there, the uppermost unit of the Miramichi Group) consisting of dark grey greywacke and black slate with some mélange of disrupted quartz greywacke suggestive of submarine slumping (Fyffe et al. 1997). The pebbles are dark grey quartzose greywacke derived from the Patrick Brook Formation. Gradationally above the conglomerate are $20 \mathrm{~m}$ of calcareous sandstone and minor pebbly sandstone, that is in turn gradationally overlain by $5 \mathrm{~m}$ of limestone and siltstone that have yielded Arenig-Llanvirn conodonts and a few crinoid fragments (Nowlan 1981; Fyffe et al. 1997). Three kilometres to the west-southwest upstream along the river, the stratigraphically equivalent conglomerate in the Patrick Brook section, consisting of granules and fine pebbles, is overlain by calcareous siltstone that has yielded middle to late Arenig brachiopods discovered by L.R. Fyffe in 1973 (Neuman 1984; Fyffe et al. 1997). It is interesting that there, the clasts in the conglomerate consist of $70 \%$ quartz in contrast to the $100 \%$ dark grey quartzose greywacke in the nearby Little Falls section. By further contrast, on the "lower" Tetagouche River near Vallée Lourdes about 9 km east-northeast downstream of the Little Falls locality, the Vallée Lourdes conglomerate, interpreted to be a debris flow (Rice and van Staal 1992), contains a few large rounded, Mesoproterozoic, unfoliated and foliated granodiorite clasts as much as a metre in diameter and abundant quartz phenoclasts derived from felsic volcanic rocks (van Staal et al. 1996) along with clasts of quartzite and felsite (Skinner 1974). The granodiorite clasts are interpreted to be a sample of possible basement to the Miramichi Group (Gander Zone) and the basement to be Avalonian or other Gondwanan, not Laurentian (van Staal et al. 1996). Finally, a lens of Vallée Lourdes conglomerate near Middle River, about $8 \mathrm{~km}$ west-southwest of the Patrick Brook locality, contains felsic volcanic clasts (C.R. van Staal, oral communication 2002). 
The conglomerate appears to rest sharply on the Miramichi and Grand Pitch strata in the few localities where the contact was observed or the interval covering the contact is narrow. Neuman (1964) first reported that the sharp contrast in lithology and style of deformation above and below the Shin Brook-Grand Pitch contact was evidence of an angular unconformity representing part of Early Ordovician and much of the Cambrian time. Neuman (1967) named the interpreted event the Penobscot disturbance that later was called the Penobscot or Penobscottian orogeny especially when applied to obduction of the Penobscot Arc (Boone and Boudette 1989; Boone et al. 1989; Berry and Osberg 1989; van Staal et al. 1998; van Staal et al. in press). Erosion of a possibly uplifted Gander margin during the Tremadoc-early Arenig may have removed extensive Miramichi strata and obducted arc before deposition of the middle to late Arenig conglomerate and volcanic rocks of the Napadogan and Lunksoos areas. In an alternative hypothesis, one we favour, a rift or a relatively narrow zone of rifts, to the southeast of the Lunksoos area and to the southeast of the Otter Slide-Burnt Hill belts of the Napadogan area during their pre-thrust, Arenig time, was associated with local uplift of Miramichi-Grand Pitch strata to erosion, the Napadogan uplift in the Napadogan area. The resulting quartz-sandstone gravel probably slumped through local submarine canyons toward the northwest. Fine-grained quartzose and pelitic sediments in the Lower Birch Island Member of the Lower Hayden belt were derived from the Napadogan uplift to the northwest or possibly, from the southeast as a continuation of Miramichi sedimentation. No convincing direct evidence of pre-unconformity deformation other than simple uplift and tilting has been described in the Miramichi Highlands. Arenig erosion probably removed only the upper, non-penetratively deformed strata and penetrative deformation and quartz veining, if any, occurred at deeper, untapped levels. Finally, evidence of erosion of structurally overlying, obducted Penobscot Arc volcanic rocks may be the volcanic clasts in the Arenig conglomerate such as in the northeastern Miramichi Highlands and the Island Falls quadrangle.

The lithology and maximum size of the clasts of the Arenig conglomerate in the Lunksoos area and the Miramichi Highlands are intriguingly varied from place to place. They range from pebbles and cobbles of simple quartzite (Shin Pond quadrangle and Napadogan area), to small pebbles of quartz and greywacke (upper Tetagouche River), to cobbles and boulders of diverse volcanic rocks and quartzite (Island Falls quadrangle), to cobbles and boulders of quartzite, felsite and basement granodiorite with felsic volcanic detritus (lower Tetagouche River at Vallée Lourdes). The differences are marked over only a few kilometres (e.g., Shin Pond and Island Falls quadrangles and along the Tetagouche River), but not every few kilometres witnesses changes (e.g., the Otter Slide and Burnt Hill belts of the Napadogan area and farther north). The thickness of the conglomerate seems to increase with an increase in average and maximum clast size (except perhaps the Vallée Lourdes locality).

The variability supports the hypothesis that the conglomerate originated near local rift faults accompanied by major subaerial uplift with erosion by vigorous streams through fault scarps. The uplift would probably be relatively narrow, wide enough to develop substantial streams but not so wide as to encompass the entire back arc. Cobbles and boulders could not have been transported far along streams or beaches, as for example those at Vallée Lourdes and the Island Falls quadrangle, and probably formed initially close to a major uplift with the accompanying rift faults with substantial vertical displacements. The rift near Vallée Lourdes may have brought up to erosion samples of the basement beneath the Miramichi strata during Arenig time and may have had the greatest throw. The volcanic clasts and detritus in these two localities may have been derived from three possible sources: from volcanic rocks intercalated in the upper layers of the Miramichi-Grand Pitch strata (a possible local source only, given the general absence of such volcanic rocks in present-day strata, but probably not in these two localities); from obducted Penobscot Arc rocks lying structurally above the Miramichi-Grand Pitch strata (quite plausible but the age and tectonic setting of the volcanic clasts must be determined by isotopic and geochemical analyses); and from hypothetical volcanic rocks formed along the rifts and essentially the same age as the conglomerate (theoretically possible but judged improbable because volcanic strata are lacking in the conglomerate units). We are intrigued by the second suggestion: Penobscot Arc rocks. Perhaps the volcanic clasts in the conglomerate are a confirmation of the former existence of an overlying obducted Penobscot Arc.

The pebbles and cobbles of quartzite of the conglomerates of the Shin Pond and Napadogan areas are interpreted to have formed close to rift-related uplifts but with perhaps less throw than the rifts near Vallee Lourdes and Island Falls and then resedimented via submarine canyons. Heavy-mineral concentrates from the conglomerates should be searched for minerals indicating ophiolitic and volcanic arc sources. The lack of volcanic clasts suggests that possible obducted Penobscot rocks were removed by erosion before deposition of the quartz sandstone gravel, or they did not exist in the vicinity. The proximity of Shin Pond simple conglomerate and Island Falls polymictic conglomerate is remarkable. Finally, the thin conglomerates with small pebbles of greywacke and quartz in the upper Tetagouche River must have been deposited farther out on the flank of the uplift and in shallow, warmer water favouring deposition of limestone. The greywacke clasts are of local origin but the source of the quartz clasts, from vein quartz, is puzzling. Could quartz-veined rock have been brought up from the basement?

The massive character of the conglomerates of the Napadogan and Lunksoos areas, their lenticular distribution and the general lack of intercalated finer sediments lend strong support to the hypothesis that the conglomerates were resedimented by debris flow(s) through submarine canyons into deeper water.

\section{Lower Birch Island Member}

Calcareous siltstone with minor felsic tuff and brachiopods on the Southwest (S.W.) Miramichi River was first named the Lower Birch Island Formation in regional syntheses by van Staal and Fyffe $(1991,1995 a)$. The description in this paper is the first to describe the unit and to assign the beds as a member of the Turnbull Mountain Formation. The name is derived from Lower 


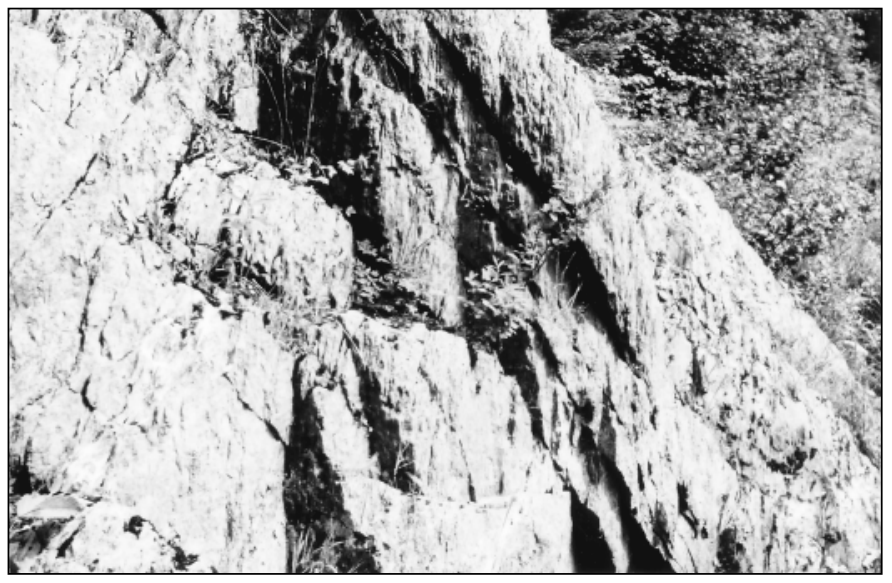

FIG. 6 Brachiopod-bearing calcareous siltstone with a few intercalated lenses of fine-grained, altered felsic tuff. Bedding, not visible in photograph, dips about 60 degrees to left (east) and the dominant cleavage is nearly vertical. Type section of the Lower Birch Island Member of the Turnbull Mountain Formation. Arenig. Lower Hayden belt. S.W. Miramichi River, east shore, $400 \mathrm{~m}$ north (upstream) from Lower Birch Island (see Fig. 2). GSC Photo 2001$383 \mathrm{~A}$

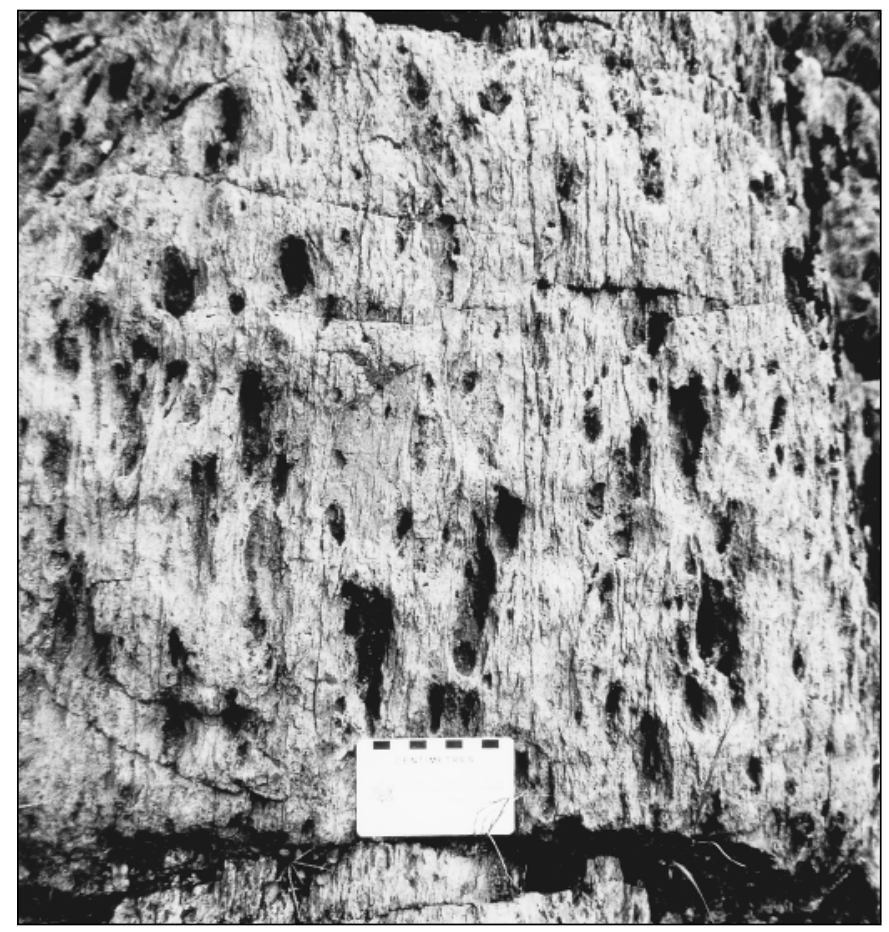

FIG. 7 Detail of exposure in Fig. 6: foliated, brachiopod-bearing calcareous siltstone with weathered-out calcite-rich pods. Bedding, not visible, dips moderately to left (east). GSC Photo 2002-724
Birch Island in the S.W. Miramichi River, about $300 \mathrm{~m}$ north (upstream) of the mouth of McBean Brook. The type section is well exposed about $400 \mathrm{~m}$ north of the island on the east shore of the river (Fig. 6). The exposures can be reached reasonably easily. A bush road off the main Rocky Brook road leads west and down to the east shore of the river, at a point about $150 \mathrm{~m}$ north of the island. The type section is a $250-\mathrm{m}$ walk north along the shore.

Irrinki (1980) placed the fossiliferous siltstone unit (i.e. Lower Birch Island Member) within the top of the Miramichi Group and described the unit as "calcareous slate containing 3-5 cm thick lenticular tuff beds" (p. 7). He placed the top of the unit at the base of the conformably overlying "red grit approximately $1 \mathrm{~m}$ thick containing calcareous siltstone pebbles" (p.9) that passes upward into maroon slate of the overlying formation. This paper differs in lithological determinations and placement of that contact.

The type section, 6 metres thick, is well exposed in a clean, large outcrop rising from the river edge. It consists mainly of foliated, light grey to greenish grey, calcareous siltstone and silty slate that is uniform and lacks bedding (Figs. 6,7). Fine detrital muscovite is common. Sericite defines the curved foliation surfaces. Two foliations separated by 20 to 30 degrees were observed by hand lens. Nodules of more highly calcareous siltstone with gradational perimeters are evenly distributed throughout most of the siltstone (Fig. 7). Most pits from weathered-out nodules are a few centimetres across but some are as much as $10 \mathrm{~cm}$ long and $5 \mathrm{~cm}$ wide. The nodules are slightly compressed parallel to the main foliation. None are arranged to suggest remnants (boudins) of once-continuous beds, although the long dimension of a few nodules is aligned at a high angle to the main foliation. A few brown-weathered fragments of beds of calcareous but more quartzose siltstone displaying faint laminae suggest flow in the host siltstone has broken the beds, pulled fragments apart by 10 to $30 \mathrm{~cm}$, and slightly rotated them. Coarse recrystallized calcarenite occurs in lenses within a few metre-size slabs and smaller blocks of siltstone that have slid downslope to the shore about $25 \mathrm{~m}$ south of the shore outcrop. The lenses are less than $3 \mathrm{~cm}$ thick and pinch out in silty slate in $20 \mathrm{~cm}$ or less. Contact of the calcarenite and enclosing slate is sharp. The siltstone in one thin section consists of about $30 \%$ subangular to subrounded quartz grains, 0.02 to $0.05 \mathrm{~mm}$ in diameter and only slightly deformed (wavy extinction under crossed nicols), within a matrix of very fine-grained micas and a trace of detrital muscovite in thin plates less than $0.5 \mathrm{~mm}$ across. Crystalline calcite in part of the thin section cements the siltstone and contains some thin curved plates suggestive of crosssections of fossil shells.

Lenses of thin beds of tuff, generally a centimetre or two thick and constituting less than $5 \%$ of the unit, are intercalated mainly in the middle and upper part of the siltstone, mark the bedding in the siltstone, and pinch out in tens of centimetres. Two types of tuff are present. The most common is a foliated, quartz-feldspar-crystal tuff in which the grains of uniform size are a millimetre or less in diameter. In thin section, feldspar crystals are equant, 0.2 to $0.5 \mathrm{~mm}$ in diameter, subrounded to subangular and completely altered to untwinned albite and fine-grained micas. Feldspar is much more abundant than quartz. Quartz is clear, undeformed, equant and subrounded to subangular. Some 
grains have scalloped, corroded edges. Sericite defines the foliation and envelopes the quartz and feldspar grains. The rarer type of tuff is a foliated, green-grey aphyric felsite with a porcelainlike texture. Weathered, disseminated, very fine-grained pyrite imparts a limonitic coating. A few small brachiopods occur in the siltstone and within the calcareous nodules. Those that appear as moulds on the clean surface of the shore outcrop seem to have remained uncompressed during deformation although perhaps broken as Ami ("fragmentary"; 1906, p. 291A) and Bailey ("much distorted"; 1906, p.281A) noted.

Both the upper and lower contacts of the Lower Birch Island Member are interpreted as conformable. The lower contact with the Miramichi Group strata at the river's edge has been offset several metres to the west, into the water, by an east-trending, steep, left-lateral cross fault. But the contact is well displayed in cliff exposures on a steep slope discovered during 2002 about 25 $\mathrm{m}$ south of the shore outcrop and about $8 \mathrm{~m}$ above the shore. The immediately underlying strata of the Miramichi Group consist of a thin light grey slate with fine detrital muscovite overlying coherent, brittle-fractured, medium-bedded quartzite. The quartzite superficially resembles a cobble and boulder quartzite conglomerate (one "boulder" as large as a curling stone) but sawcut surfaces by L.R. Fyffe clearly revealed the non-sedimentary, fracture structure. The Lower Birch Island Member lying above the thin slate and fractured quartzite consists of about $0.6 \mathrm{~m}$ of slightly calcareous siltstone lacking more-calcareous parts, that grades upward into typical wavy-foliated calcareous siltstone with sericitic foliation surfaces, fine detrital muscovite and more-calcareous lenses and nodules. The lenses of calcarenite in the slabs on the shore were not located in the outcrop. The siltstone-slate contact appears conformable and apparently not gradational through interbedding. A depositional hiatus may exist between the two sequences.

The upper contact of the Lower Birch Island Member is exposed in two nearby outcrops at the type section - on the shore and in the cliffs. The contact in this paper is placed at the top of the one metre of intercalated tuffaceous beds, in contrast to Irrinki (1980) who placed the contact at the bottom. Thus, all the tuff in these exposures is placed in the Lower Birch Island Member, and the overlying maroon formation lacks tuff and calcareous siltstone in these exposures. Further, the "red grit with siltstone pebbles" of Irrinki (1980) is interpreted herein as coarser tuff rather than a sediment that would imply a disconformity and erosion. Between the maroon slate above and the light grey calcareous siltstone below is a metre or more of interbedded siltstone, maroon ferruginous slate and sandy tuff. The interbedding in this transition zone conceivably could have resulted from structural interleaving from bedding-parallel movement, but we doubt it. The siltstone and tuff in this transition zone are reddish grey, presumably stained by hematite from the intercalated and overlying maroon beds during weathering. Of interest is that fine detrital muscovite occurs in both the Miramichi strata and the Lower Birch Island siltstone, which along with the conformable relations, suggests that Miramichi deposition from a southeastern source may have continued into Lower Birch Island deposition in the Lower Hayden belt. However, we suggest that both silt and brachiopods were derived from the eroding Miramichi strata in the Napadogan uplift to the northwest.

The calcareous siltstone was probably deposited in quiet waters at or below wave base near colonies of brachiopods in water depths not as deep as that envisaged for Miramichi strata. Movement along the older foliation surfaces would account for the lenticular nature of the intercalated tuff and calcarenite beds. The younger, main, foliation intersected the tuff beds at about 30 degrees to the beds without significant attenuation or dismemberment parallel to the foliation and did not flatten the brachiopods or the calcareous nodules appreciably.

Alternatively, the calcareous siltstone may have been deposited as mass grain flow(s) (as suggested by L.R. Fyffe in discussion with Poole at the type section, 2002). Consistent with this hypothetical interpretation are features such as the lack of bedding in the siltstone, lenticular nature of the tuff beds as if pulled apart by grain flow or bedding-parallel movement, intercalated fragmented siliceous siltstone beds, and broken brachiopods. Thus, the tuff beds would have been pulled apart in a weak silt-water medium during final emplacement by mass slumpage rather than by penetrative deformation.

\section{Distribution of Lower Birch Island Member}

The Lower Birch Island Member, like the underlying Upper Buttermilk Member in the northwest, varies from place to place throughout the Napadogan area in its lithology, apparent thickness and its presence or absence along its stratigraphic horizon (Fig. 8). The felsic tuff is commonly thin, soft and easily eroded, is thicker in northwestern localities and has yielded brachiopods (Fig. 2). Mafic tuff occurs at the top of the member in several localities and a mafic flow in two other nearby localities. Sandstone and slate with brachiopod shells underlie felsic tuff in one locality in the northwest. Mudstone and siltstone with brachiopods dominate in the southeast. The member is distributed as follows (Fig. 2): a) along the faulted southeastern border of the Lower Hayden belt are two exposures of Lower Birch Island rocks, preserved in fault horsts or enclaves sheltered from the master fault, the Bamford Brook Fault (Poole 1963; Irrinki 1980; Fyffe 1982); b) along the faulted southwestern end of the Burnt Hill belt are several fault slices carrying the member; and c) along the faulted southeastern edge of the Otter Slide belt are several fault slices with the member, three of them fossiliferous.

\section{Lower Hayden belt}

Fossiliferous Lower Birch Island Member occurs in two enclaves along the Bamford Brook Fault on the southeast side of the Lower Hayden belt (Figs. 2, 8). On the lower parts of the Middle Hayden and nearby Lower Hayden brooks, about 19 $\mathrm{km}$ southwest of the Lower Birch Island type locality, the Lower Birch Island Member consists of about 6 metres of steeply dipping, thin-bedded, medium grey calcareous argillite, silty argillite and siltstone, overlying the Miramichi Group on the northwest, conformably and perhaps gradationally. Along Middle Hayden 


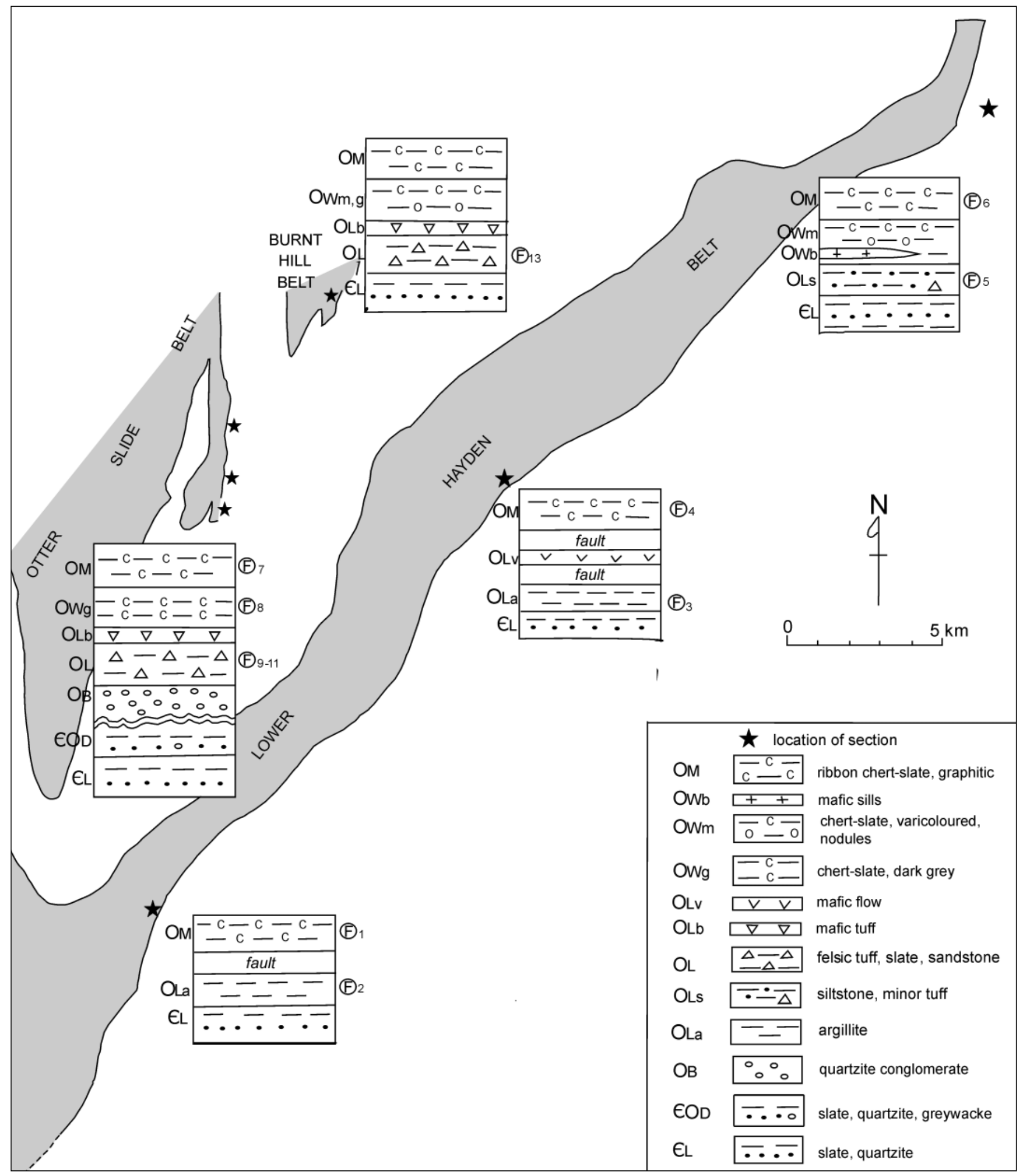

FIG. 8 Generalized stratigraphic sections at brachiopod-bearing localities in the Napadogan area, illustrating the stratigraphic differences from locality to locality. Geology by Poole, unpublished. Miramichi Group shaded. No implication of thickness of strata. Legend as on Fig. 2. 
Brook, the underlying exposed Miramichi strata consist of about $45 \mathrm{~m}$ of open but complexly folded, thin-bedded, light grey to greenish grey, slaty argillite and laminated siltstone with intercalated quartzite in thin to medium beds. Calcareous argillite in the top $0.5 \mathrm{~m}$ of the 6-metre sedimentary sequence of the member bears brachiopods and conodonts, the Middle Hayden fossil locality (Fig. 2). The contact between the Miramichi strata and the Lower Birch Island argillite and siltstone is difficult to identify because the lithology of the two units is similar although exposures along the brook are excellent. Strata with quartzite are assigned to the Miramichi Group and those at the top of the sequence lacking quartzite and more calcareous are assigned to the Lower Birch Island Member. All these strata lack volcanic detritus and tuff. The fossiliferous strata are faulted on the southeast against basalt (5-metre covered interval) that is tentatively assigned to the upper part of the Lower Birch Island Member. The basalt is in turn faulted against Caradoc graphitic slate-chert on the southeast. The basalt is light green-grey, mildly schistose, medium- and fine-grained, and aphyric, from 50 to $80 \mathrm{~m}$ thick (if it is monoclinal and dips 60 degrees), and extends for about $5 \mathrm{~km}$ along strike. One flow or more may exist; outcrops are discontinuous and flow contacts are not exposed along the Middle Hayden Brook or Upper Hayden Brook. White and in places red calcite and chlorite fill amygdules in part of the flow (or flows). The rock has been thoroughly altered to a greenstone assemblage of albite, epidote, chlorite and sericite.

In the second enclave, about $18 \mathrm{~km}$ farther to the southwest on an unnamed small tributary of Rocky Brook, occur 3.5 metres of steeply dipping, interbedded, light yellow-grey to light grey argillite, calcareous argillite and minor siltstone. These strata are assigned to the Lower Birch Island Member, are faulted against Caradoc graphitic slate-chert on the southeast and, on the northwest, are separated by a covered interval of several tens of metres along the tributary from thin-bedded, greenish grey slate and thin-bedded quartzite of the Miramichi Group. Much of the argillite contains disseminated, very fine-grained pyrite, that with the abundant pyrite in the nearby slate-chert, on weathering, has leached the carbonate and brachiopods from the rock. No tuffaceous strata or tuff were observed although possibly some of the very fine-grained "argillite" may have a volcanic component. The fossil layer, the Rocky Brook fossil locality (Fig. 2), occurs near the stratigraphic top (southeast side) of the argillite near the fault and is difficult to locate. The weathered top of the outcrop, a "brown pulverulent mass", yielded brachiopods from a 5-cm layer (Robb 1870, p. 190). Such thin, soft, easily eroded strata may well exist along the southeastern edge of the Lower Hayden belt in undiscovered enclaves preserved along the Bamford Brook Fault.

Along the northwestern edge of the Lower Hayden belt, Llanvirn and Caradoc strata, younging northwest, overlie Miramichi slate and quartzite and Arenig strata, if present, are not exposed. The Turnbull Mountain Formation was observed in only one road crossing along $40 \mathrm{~km}$ of the Miramichi-Llanvirn contact. There, along a logging road between the headwaters of the Middle Hayden and Lower Hayden brooks (Fig. 2), a few metres of rubble of altered mafic volcanic rock assigned to the Lower Birch Island Member lies between Miramichi Group slate-quartzite rubble and Llanvirn medium grey chert-slate rubble. The volcanic rock is a granular, fine- to medium-grained, aphyric, light green-grey assemblage of untwinned, bent and broken albite, much chlorite in aggregates and microveinlets, and some epidote and titanite as seen in thin section. It seems probable that Lower Birch Island strata exist along some or much of the northwestern edge of the Lower Hayden belt, perhaps in part lithologically similar to those of the Lower Birch Island locality.

\section{Burnt Hill belt}

A belt of the Turnbull Mountain Formation, Llanvirn greymaroon slate-chert and Caradoc graphitic slate-chert in the Burnt Hill belt, lying between the Miramichi Group strata on the northwest and the Caradoc-Ashgill slate-greywacke on the southeast (Fig. 4), extends for $10 \mathrm{~km}$ from the Upper Hayden road northeasterly to the S.W. Miramichi River and beyond (Poole 1963; Crouse 1981a; Irrinki 1981). At the southwest end, in the Napadogan area, these rocks for about $5 \mathrm{~km}$ between the Upper Hayden and Mine roads consist of narrow wedge-like fault slices of strata trending northeast, and lying northwest of the eastnortheast-trending master fault adjoining slate-greywacke (Figs. $2,4)$. The Burnt Hill belt pinches out towards the southwest in a "tail" of graphitic slate-chert marking the trace of the master fault within the broad area of slate-greywacke (Fig. 2).

Felsic tuff occurs in five thin fault slices in the Burnt Hill belt and all but the southeasternmost one pinch out toward the northeast in thin-bedded Miramichi Group slate and quartzite along strike faults (Fig. 4). The tuff is light greenish grey, weathered to buff to light brown and consists of foliated quartz-crystal tuff with crystals less than $2 \mathrm{~mm}$ in diameter, grading to massive, aphyric sandy and silty tuff to lapilli tuff with very fine-grained aphyric fragments. The fragmental character of the tuff is visible only on clean weathered surfaces. In thin section, quartz crystals are equant, clear and undeformed, and in one thin section of a lithic lapilli tuff, a quartz crystal is a stubby bipyramidal prism, the high temperature form. In some varieties, quartz crystals "float" in a very fine-grained, foliated sericite-chlorite matrix that curves around the crystals and that supposedly was fragmental before alteration and deformation. Rare feldspar crystals have been altered to untwinned albite, sericite and chlorite. All these rocks are rich in clay from Quaternary weathering. Traces of pyrite have weathered to limonite and coloured the rocks a light orangebrown. Mafic tuff, massive, schistose, medium green to greengrey, appears in the fault slice along the southeast side, adjacent to the Llanvirn strata. Clasts in the fine ash are in the 0.1 to $1 \mathrm{~mm}$ range and consist mainly of very fine-grained chlorite and some carbonate. Feldspar has been altered to mainly sericite. The matrix contains chlorite, sericite, epidote and calcite with rare equant quartz crystals rimmed with chlorite. The thickness of strata in the slices is impossible to estimate. Cross-strike widths of formations vary from zero to $300 \mathrm{~m}$ and undetected internal repetition by fault-slicing in the thicker sections is most probable.

An unusual fossiliferous sediment, tentatively assigned to the Lower Birch Island Member, occurs along an old logging road about $0.7 \mathrm{~km}$ south of the junction of the Mine road and the 
Lower Hayden road (Fig. 4). There, rubble along 11 metres of road aligned across the bedrock strike consists of light greenish grey, mudchip quartz sandstone and some granule conglomerate interbedded with light greenish grey slate and siltstone. The chips and granules consist of silty mudstone and siltstone, indicative of vigorous water flow. These rocks lack volcanic detritus and have some detrital muscovite. The sandstone and conglomerate weather readily to orange-brown to medium brown (limonitic) from a percent or two of iron-bearing carbonate cement and pyrite in the matrix. A few brachiopod fragments were found in the mudchip sandstone within a few metres stratigraphically below crystal tuff (the Headwaters of the Middle Hayden fossil locality, Figs. 2, 4). These strata, unfortunately poorly exposed, are unlike other strata that host brachiopods in the Lower Hayden belt, and until more exposures are examined, they remain somewhat enigmatic.

\section{Otter Slide belt}

About $4 \mathrm{~km}$ to the southwest of the Burnt Hill belt, in the Turnbull Mountain-Otter Slide Mountain area (Figs. 2, 3), Miramichi Group slate and quartzite have apparently been thrust eastward against Caradoc-Ashgill slate-greywacke. Between these two units are narrow discontinuous fault slices of the Turnbull Mountain Formation and younger Ordovician units. The Lower Birch Island Member consists of massive, very fine-grained, aphyric, light greenish grey to grey to ivory, fine- to coarse-grained felsic lithic tuff with disseminated fine pyrite, and massive "argillite" that is white-weathering and probably a very fine-grained tuff, perhaps originally a volcanic dust. The "argillite" is medium to light grey and very weakly foliated. Porphyroblasts likely of calcite in the form of thin plates are characteristic; some have a hexagonal outline, and all have been removed by weathering. The plates, as much as perhaps $5 \%$ of the rock, are generally $2 \mathrm{~mm}$ in diameter and 0.1 to $0.3 \mathrm{~mm}$ thick. They are clearly younger than the foliation, and thus may be related to emplacement of the Devonian granite to the west. Three discontinuous slices have yielded fossils but such have not been found in six nearby subparallel slices. Thin mafic tuff overlies the felsic tuff in one slice.

The next westerly occurrence of Lower Ordovician felsic volcanic rocks lies several kilometres to the west of the southern extension of the Otter Slide belt, in the headwaters of Napadogan Brook (Lutes 1981), outside of the Napadogan area discussed here. C.R. van Staal (oral communication, 2002) believes that these Napadogan Brook volcanic rocks are an extension of the Meductic Group from the south (Fyffe 2001) and not a continuation of the Lower Birch Island Member. Their early to middle Arenig age along with the geochemistry of the volcanic rocks (Fyffe 2001), help distinguish them from Lower Birch Island volcanic rocks.

\section{Lithology and Origin of the shell beds}

What lithological terms to apply to the brachiopod-bearing volcanic rock in the Napadogan area is uncertain, and depends upon the envisaged mode of formation of the fossiliferous rock. On the outcrop, the rock appears massive except for layers of shells. In thin section, it appears commonly fine-grained $(<0.1 \mathrm{~mm}$ in some localities with quartz as large as $0.5 \mathrm{~mm}$ ), equigranular and massive, and appears to consist mainly of clay and quartz with some limonite after disseminated fine-grained pyrite cubes. All components appear to be felsic volcanic rock. We suggest that the bulk of the host rock was probably airborne volcanic ash and dust that settled in marine waters below wave base. If this interpretation is correct, the applied lithological terms should emphasize the pyroclastic origin rather than a sedimentary one. For that reason, we use terms such as sandy, silty and clayey tuff. Tuffaceous sandstone and related terms imply that the rock consists substantially of detritus derived from weathering products, that the source rock was weathered subaerially, that water action was significant and that the resultant deposit is bedded.

Shell beds, in unusually high concentrations, occur within the Shin Brook Formation (Fig. 9) and in the Lower Birch Island Member of the Otter Slide belt. Brachiopods in each unit are concentrated in layers dominated by a single species within otherwise massive sandy tuff. Most brachiopod valves are unbroken and unabraded, and are oriented in a hydraulically stable, convex-sideup position. Ventral valves outnumber dorsal valves by perhaps 10 to 1; presumably the normally highly indented dorsal valves were washed away from of the site. Thus, water currents sorted and oriented the valves but did not break or abrade them. In a large block from the Lunksoos area (Figs. 9, 10), a few shells immersed in a 5 -cm layer of sandy tuff are aligned at about 45 degrees to the shell beds lying above and below, suggestive of internal soft-stage movement after initial deposition. The upper shell bed of the specimen has slid subparallel to bedding, crumpled and ridden upward $3 \mathrm{~cm}$.

Kidwell and Aigner (1985) studied shell beds in Miocene strata in Maryland, U.S.A., and concluded that the shells became concentrated from normal concentrations by winnowing of the accompanying fine-grained sand matrix. Kidwell (1986) explained some shell concentrations to result from variation of sedimentation rate while the rate of production of shells remained more or less constant.

It appears that in the Shin Brook shell beds of Figs. 9 and 10, water currents did not play a major roll in sedimentation of the tuff since mineralogical bedding did not develop, but gentle currents prevailed. Winnowing was probably not involved in producing our Arenig shell beds. Rather, we favour a high shell production rate in a nutrient-rich environment on a new layer of ash during a period of quiescence between volcanic eruptions. As such, we have adapted the lead of Kidwell (1986).

\section{Correlatives of the Lower Birch Island Member}

The felsic volcanic rocks of the Shin Brook Formation are a lithological and time correlative of the Lower Birch Island Member of the Turnbull Mountain Formation, despite the marked difference in unit thickness and texture of the volcanic rocks. These volcanic rocks in the Shin Pond quadrangle consist of a maximum of $750 \mathrm{~m}$ from the base to a cap of a metadiabase sill at the top of the exposed sequence. The sill has intruded the Shin Brook strata and perhaps, but not assuredly, is of Shin Brook age (Neuman 1967). Above the local pebble conglomerate, the Shin Brook Formation consists of 


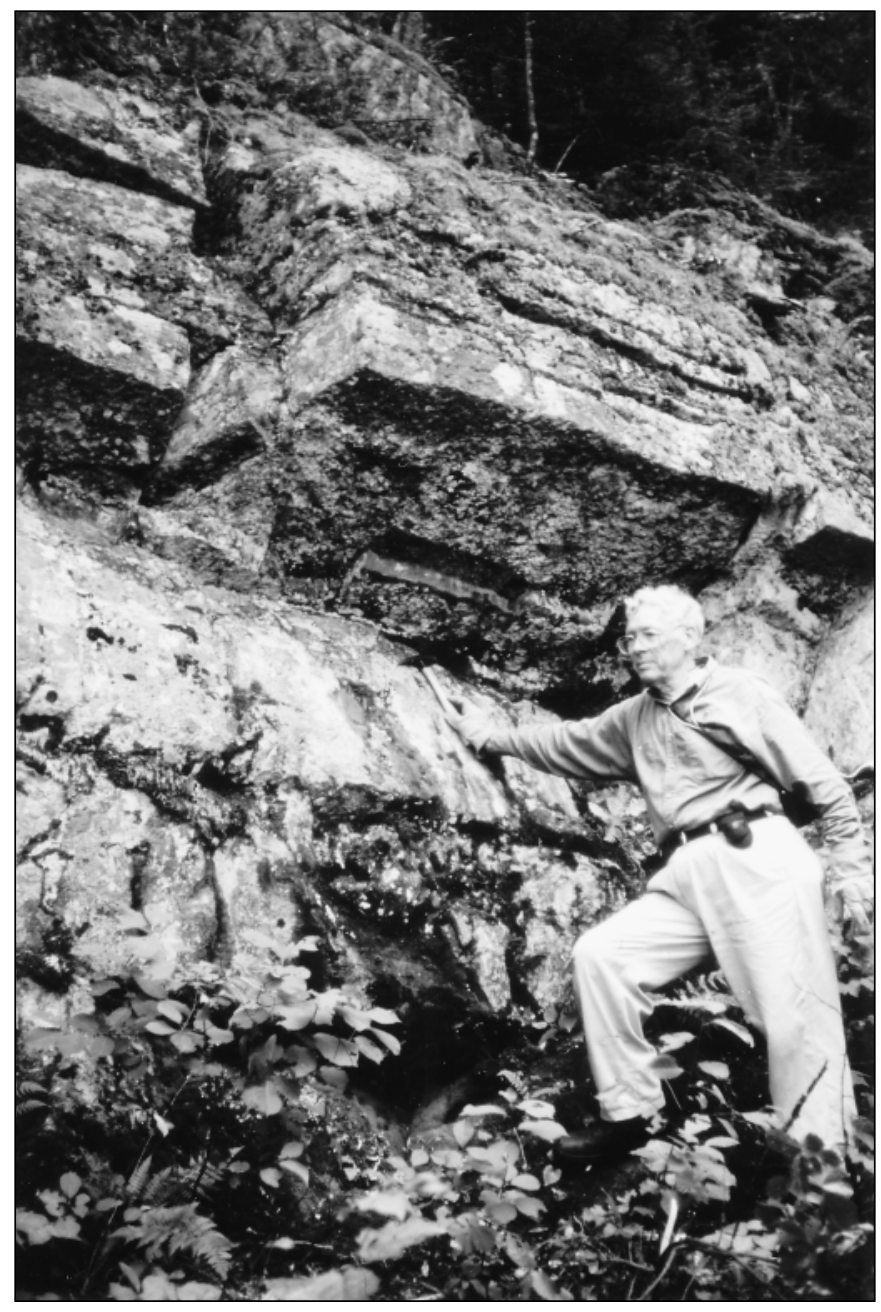

felsic tuff, breccia and volcanic sandstone. Most common is grey to greenish grey feldspar-phyric lapilli tuff in thick and thin beds. Rare are probable flows and ignimbrite. Slate, siltstone and sandstone consisting entirely of volcanic detritus form a minor part of the formation. What proportion of the felsic tuff is simply waterlain or was carried in water for at least a short distance as a turbidity current, slurry or mass flow is difficult to estimate. Indeed, all of the tuffaceous rocks with fossils were deposited in water as well as those probably lacking fossils. Some volcanic sandstone (sandy tuff) beds are richly fossiliferous with brachiopods, some trilobites and bryozoans and rare gastropods (Neuman 1964). Some beds grade upward from coarse- to fine-grained sandstone and others from fine-grained sandstone to slate. Exotic rock fragments have not been recognized. The Shin Pond volcanic rocks extend into the adjacent Island Falls quadrangle where they are as much as $300 \mathrm{~m}$ thick and consist of slaty felsite, coarse-grained calcareous tuffaceous sandstone and ash-flow tuff(Ekren and Frischknecht 1967). Volcanic rocks in the Mount Chase belt, mainly basalt lavas and sills plus slate and pyroclastic rocks, are exposed in a fault-block several kilometres to the southeast of the Shin Brook volcanic belt. They have been interpreted to overlie the Shin Brook Formation and are presumed to be of the same age at least in part (Ekren and Frischknecht 1967).

In the northeastern Miramichi Highlands, volcaniclastic strata

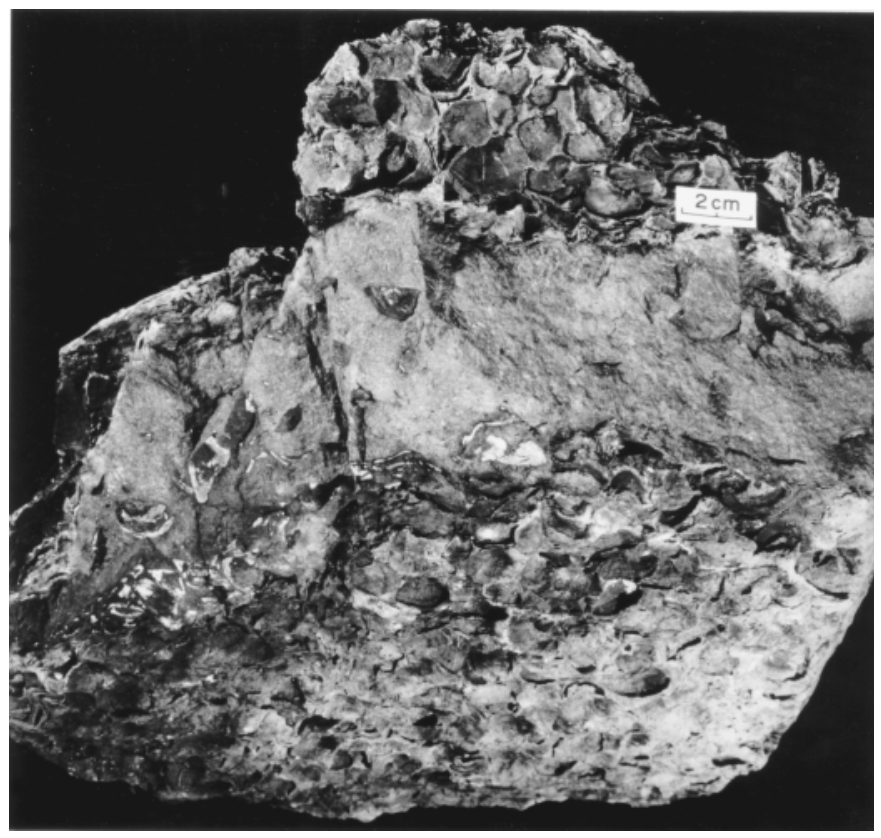

FIG. 10 (Above) Block from outcrop in Fig. 9 showing abundant brachiopods on top and bottom surfaces. Arenig. Shin Brook Formation, Lunksoos area. GSC Photo 2001-383C

FIG. 9 (Left) Brachiopod-rich layers in sandy felsic tuff of the Shin Brook Formation. Arenig. The tuff is massive and lacks bedding but for the abundant shell beds. William H. Forbes, master fossil finder. Lunksoos area, SugarloafMountain, about $0.5 \mathrm{~km}$ south of peak. GSC Photo 2001-383D

of the Little Falls Member of the Nepisiguit Falls Formation, overlying the Vallée Lourdes Member along the Tetagouche River, is a lithological and time correlative of the Lower Birch Island Member but lacks brachiopods and is much thicker. There, about $30 \mathrm{~m}$ of thick-bedded, medium- to fine-grained, quartz-feldsparcrystal-rich volcaniclastic sandstone, crystal tuff and ash tuff of the member have been interpreted as a sedimentary sequence (Little Falls section; Fyffe et al. 1997). A hand-picked sample of needlelike zircons (amongst a varied population) extracted from quartzfeldspar crystal tuff of this unit near Tetagouche Falls $1.7 \mathrm{~km}$ west of Little Falls, and believed to be essentially free of an inherited component, yielded a concordant age of $471 \pm 3$ and $469 \pm 9 \mathrm{Ma}$ $\left({ }^{206} \mathrm{~Pb} /{ }^{238} \mathrm{U}\right.$ and ${ }^{207} \mathrm{~Pb} /{ }^{235} \mathrm{U}$, respectively). Zircons from near the top of the formation $25 \mathrm{~km}$ to the south yielded a concordant age of $469 \pm 2 \mathrm{Ma}$ (Sullivan and van Staal 1996). The interpreted age of the Nepisiguit Falls Formation is 470 Ma, i.e. middle to late Arenig if the Arenig extended from about 480 to $465 \mathrm{Ma}$ (McKerrow and van Staal 2000). The age of the brachiopod-bearing Vallée Lourdes is thus constrained to the Arenig, probably late Arenig, along with the volcanic rocks of the Little Falls Member. Confirmation of these ages is provided by the overlying Flat Landing Brook Formation of felsic flows, pyroclastic rocks and interlayered tholeiitic basalts and maroon shales and siltstones (van Staal et $a l$. in press). Three $\mathrm{U}-\mathrm{Pb}$ zircons ages from the formation indicate 
a late Arenig to early Llanvirn age. It thus seems most probable that the Upper Buttermilk and Lower Birch Island members of the Turnbull Mountain Formation are also late Arenig age or possibly middle to late Arenig age.

In summary, the Turnbull Mountain Formation with its two members of differing lithology varies across the Napadogan area. The Upper Buttermilk quartzite conglomerate occurs only in the northwest, and probably originated by uplift and erosion of Miramichi light grey mudstone and sandstone along a rift fault or faults accompanying the hypothetical Napadogan uplift located probably southeast of the Otter Slide and Burnt Hill belts in their original Arenig pre-thrust positions. Vigorous stream erosion and transport deposited the gravel on submarine stream fans. The gravel subsequently flowed northwestward into deeper water through submarine canyons that were cut into the outer edges of the uplifted belt. Earthquakes associated with rift-related faulting and volcanism triggered the slumping. Canyon transport is believed to account for local, lenticular distribution of the conglomerate. Meanwhile, southeast of the uplift, turbidity currents from the southeast may have continued to deposit Miramichi Group sediments on the continental slope. No interbedding of conglomerate and fine-grained Miramichi Group strata has been observed. The overlying Lower Birch Island Member also varies widely from place to place across the Napadogan area. Felsic volcanic rocks are exclusively tuffs, are thickest in the northwest and are absent to the southeast where fine-grained, non-volcanic sediments take their place with a mix of the two in the middle (Lower Birch Island type locality). A mafic flow (or flows) occurs locally in the southeast, but elsewhere the minor mafic volcanic rocks appear to be only tuffs. Mafic tuff and flows are much more abundant within several tens of kilometres to the northeast of the Napadogan area. These relations support a model in which the three belts within the Napadogan area represent thrust slices brought together from the northwest and from more widely separated locations than currently positioned.

The siltstone and mudstone deposited to the southeast of the Napadogan uplift was probably derived from the Napadogan uplift to the northwest along with their Celtic fossils. Perhaps a less likely source is to the southeast as a continuation of Miramichi sedimentation. In either case, the resulting strata could be lithologically the same.

\section{BRACHIOPODS}

Brachiopods of late Arenig age have been found in seven localities in the Napadogan area, all in the Lower Birch Island Member. Below is a description of each site and the history of identifications as understanding of the age of the assemblage developed through 130 years of paleontological research. Then will follow a summary table of the current view on identification and some notes on the genera.

\section{Rocky Brook locality}

The first known brachiopod locality in the Napadogan area, the Rocky Brook locality, was discovered by Edward Jack, a civil engineer and land surveyor, who in 1867 "communicated that fact [existence of the fossil locality] in a short note to the Natural History Society of St. John (sic.).” (Robb 1870, p.190). The locality is located on an unnamed tributary that flows westward into Rocky Brook (that joins the Nashwaak River) $0.5 \mathrm{~km}$ south of Valley Forest road (Fig. 2; Poole 1958; Crouse 1981b). The locality is $1.2 \mathrm{~km}$ due east of the mouth of the tributary (zone $19659680 \mathrm{E} 513282 \mathrm{~N} \mathrm{FB})$. Charles Robb was led to the locality by Jack in 1868. Elkanah Billings identified from Robb's collection (GSC loc. 3157): Chonetes canadensis, Leptoccelia flabellites, Renssellaria ovoides, Strophomena perplana, and Streptorhyncus sp. indet., and correlated the rocks with the Upper Silurian and Devonian Gaspé limestones (Robb 1870). The locality became a small belt of Silurian-Devonian within a broad area of unfossiliferous strata presumed to be Cambro-Silurian, later known as Ordovician (Bailey et al. 1886). Poole recollected the locality about 90 years later, in 1957 (GSC loc. 32399), and L.M. Cumming identified: ?Tritoechia sp. or ?Schuchertella sp., Hesperonomia? sp., brachiopod genus A and brachiopod genus B. He interpreted the age as Ordovician or Silurian and observed that some brachiopods resembled those from the Lower Ordovician Luke Hill Formation of southern Québec (Globensky 1981; GSC internal report O or S-3-57/58-LMC). In 1959, Poole led Cumming and A.J. Boucot to the locality, and Boucot orally declared the locality not to be Silurian or Devonian but Ordovician. From the resulting collection (GSC loc. 40749) Cumming identified: Orthambonites sp., Dictyonema sp., ?Reuschella sp. cf. R. horderleyensis, and ?Dolerorthis sp. (GSC internal report O-1-1963-LMC). In the same report, he recorded: "Professor Alwyn Williams ... briefly examined this collection during April 1962 and voiced the opinion that the brachiopods were Ordovician forms and probably Caradoc in age." Cumming noted that Orthambonites is Lower to Middle Ordovician. During 1966, Neuman examined the fossils in GSC loc. 40749 and identified: Orthambonites, Productorthis, Tritoechia, ?Taphrorthis, and a new genus of syntrophid (Neuman, written communication to Cumming, 1967). Neuman collected the locality in 1967 and identified: new genus aff. Glossorthis (13 specimens), new genus aff. Henellina (21), Orthambonites sp. (35), Porambonites sp. (4), Productorthis sp. (2) and Tritoechia sp. (11) (Neuman, written communication to R.R. Potter, 1968). In a subsequent publication, Neuman (1968) grouped all brachiopods identified from the Rocky Brook, Lower Birch Island and Middle Hayden localities as: Productorthis mainensis Neuman (uncertain species identification), Orthambonites robustus Neuman sp., Valcourea sp., Tritoechia billingsi Neuman, new genus of syntrophid and Eodalmanella sp., and suggested that they were probably Llanvirn in age. A sample for conodont search, collected in 1978 by G.S. Nowlan and Poole (GSC loc. 96069), proved to break down poorly and was found to be barren of conodonts (Nowlan 1981). Neuman $(1971,1984)$ listed all the brachiopods together from the Rocky Brook, Lower Birch Island and Middle Hayden Brook localities; those on the list appearing in Neuman (1984) 
(and in brackets, the new species described by Neuman 1971), are: Munhella (M. cummingi Neuman), Orthambonites, Productorthis, Tritoechia, Fistulogonites, Schedophyla (S. potteri Neuman) and Rugostrophia (R. sylvestris Neuman). Neuman (1971) interpreted the age as Arenig and Neuman (1984) stated Arenig but late Arenig for the Shin Brook Formation. To our knowledge no other collections from the Rocky Brook locality have been made and studied since 1978.

\section{Lower Birch Island locality}

The second brachiopod locality discovered in the Napadogan area, the Lower Birch Island locality, occurs at the type section of the Lower Birch Island Member and is located along the east shore of the S.W. Miramichi River, $400 \mathrm{~m}$ north (upstream) of Lower Birch Island (Fig. 2; zone 19 68614E 516032N FB). Fossil shells were first noted by R.W. Ells in 1880 as "imperfect fossils at one point" but he did not collect them (Ells 1881, p. 22D). A compiled regional map, 1 inch to 4 miles, published a few years later (Bailey et al. 1886), does not indicate the locality, but a fossil symbol marked $4 \mathrm{~km}$ downstream, may have been misplaced on the map. Some years later, Bailey (1906) relocated and collected the locality. Ami (1906) remarked on the fragmentary nature and poor preservation of the fossils (GSC loc. 2141), and identified: Orthis sp. indet., Rhynchonella sp., Homoeospira sp., Lingula sp. and Spirifer sp., and stated the collection "may be Silurian". More than 50 years later, Poole recollected the locality in 1957 (GSC loc. 32398; Poole 1960) and Cumming identified: Orthis sp. cf. O. panderiana Hall and Clarke, brachiopod genus A, brachiopod genus B and brachiopod genus $\mathrm{C}$ (GSC internal report O or S-3-57/58-LMC). Genus A and genus B were also found at the Rocky Brook locality. Cumming was uncertain whether the collection was Silurian or Ordovician, but, as with the Rocky Brook locality, he seemed to favour an early Ordovician age. Neuman examined some GSC collections on loan in 1966-67 and reported to Cumming that he identified Orthambonites (Neuman, written communication to Cumming, 1967). Later during 1967, Neuman visited the locality, guided by R.R. Potter, and identified: new genus aff. Aporthophylla (2 specimens), new genus aff. Glossorthis (1), Orthambonites sp. (6), and Productorthis (1) (Neuman, written communication to Potter, 1968). Neuman $(1968,1971,1984)$ grouped all brachiopods from the Rocky Brook, Lower Birch Island and Middle Hayden Brook localities, as described above, under the Rocky Brook locality. In 1978, Nowlan and Poole collected the locality for a conodont search. Unfortunately, sample GSC loc. 96066 broke down poorly in acids, yielding only "two simple cone elements assignable to the form genus Oistodus Pander" and was of little use in determining an age (Nowlan 1981).

In 2002, Poole collected two samples of coarse, recrystallized calcarenite discovered in blocks of calcareous siltstone that had slumped to the shore from uphill exposures near the type locality. Fortunately the samples yielded conodonts that, although fragmentary, do clearly constrain the age of the brachiopods to late Arenig. Nowlan reported (GSC internal report 004-GSN-2003) that one sample (GSC loc. O-108217) yielded Protopanderodus sp. (one specimen) and Tripodus sp. (7), and the second sample
(GSC loc. O-108218) yielded Drepanoistodus sp. (1) and Tripodus sp. (10), all thermally altered to CAI 5 . Nowlan commented on both samples: "This modest fauna of simple cone elements is the first identifiable conodont material to be recovered from this locality that yields late Arenig brachiopods (see Nowlan 1981). The specimen assigned to Protopanderodus sp. is most similar to Protopanderodus rectus (Lindström). The fauna is dominated by specimens assigned to Tripodus. The type species of this genus is Tripodus laevis Bradshaw, the zonal index for the base of the Whiterock Series in North America. The present material is not conspecific with T. laevis but is likely a separate species. Several occurrences of other species of Tripodus are known, although none is formally named. For example, the genus is known to occur in the Latorp Limestone of Arenig age in Sweden (personal communication R.L. Ethington and comparative specimens examined) and in the upper McKay Formation and lower Glenogle Formation in British Columbia (Norford et al. 2002). The specimens recovered herein are similar to the forms present in the Latorp and Glenogle formations which are of late Arenig age (D. bifidus graptolite Zone and O. evae conodont Zone), slightly older than the base of the Whiterock Series. The age of the sample is therefore late Arenig (Blackhillsian; late Ibexian in North American stadial nomenclature)." To our knowledge, no other fossil collections and studies have been carried out at the locality.

\section{Middle Hayden Brook locality}

The locality most productive of paleontological and age information is the Middle Hayden Brook locality, discovered by Poole in 1958. It occurs on Middle Hayden Brook, west bank, $180 \mathrm{~m}$ south (downstream) of a logging haulage road ("Cross road”; Fig. 2; zone 19 67095E 514703N FB). Cumming identified: ?Eatoniodes sp. cf. E. lamellornatus McLearn plus two other forms later deleted following reconsideration (GSC loc. 36562; GSC internal report O-S-1-59/60-LMC). In 1962, Alwyn Williams briefly examined the collection, identified Orthis (Nicolella) Reed sp. and Clitambonites sp., and regarded the collection as Ordovician (GSC internal report O-1 1963 LMC). Neuman studied the collection in 1966-67 and reported Orthambonites and "?Taphrorthis" (Neuman, written communication to Cumming, 1967). Later during 1967, Neuman collected the locality and identified: new genus aff. Aporthophylla (30 specimens), new genus aff. Huenellina (21), Orthambonites sp. (100+), Porambonites sp. (3) and Tritoechia sp. (30) (Neuman, written communication to Potter, 1968). Eleven years later, Nowlan, Poole and L.R. Fyffe collected a sample for conodont search (GSC loc. 96067) that, fortunately, yielded 27 conodont elements, although most are broken and thermally altered to CAI 6. Nowlan (1981) identified: Drepanoistodus sp. (2 specimens), Microzarkodina flabellum (Lindström) (four forms totalling 15 specimens), Oistodus sp. (1 specimen), Protopanderodus rectos? (Lindström) (6), and Walliserodus? sp. (3), and interpreted the age as "may range from early Middle Arenigian to earliest Llanvirnian", thus supporting the Arenigian brachiopod age interpretation of Neuman (1968). Neuman $(1968,1971,1984)$ grouped all brachiopods together, as explained above under the Rocky Brook locality. A small col- 
lection by Poole in 1999 (GSC loc. O-108212) failed to provide brachiopods other than those already known (Neuman, written communication to Poole, 1999).

From 1997 to 2000, four new brachiopod localities were discovered and were named for convenience the North Taxis Road, Turnbull Mountain, Long Hill and Headwaters of Middle Hayden Brook localities (Fig. 2). The first three are situated along a line 3 $\mathrm{km}$ long in the northwestern Napadogan area, representing the trace of the Lower Birch Island Member, sliced and separated by strike faults along the eastern edge of the Otter Slide belt (Fig. 3). The fourth lies $5 \mathrm{~km}$ to the northeast within the similarly sliced, southwestern end of the Burnt Hill belt (Fig. 4). Brachiopods from all four localities are moulds and many details have been lost by dissolution of carbonate in the current weathering zone. The lack of a carbonate host rock severely hindered a search for conodonts.

\section{North Taxis Road locality}

The North Taxis Road locality, the first found of the four, was discovered by Poole in 1997. It occurs along a logging road, referred to informally by Poole as the North Taxis road (Fig. 3), 1.1 $\mathrm{km}$ southeast of the junction with the main Napadogan haulage road that leads $7 \mathrm{~km}$ south to the Bowater gate at Napadogan(i.e. about $1.4 \mathrm{~km}$ at $045^{\circ}$ azimuth from Turnbull Mountain; zone 19 66165E 5147732N FB). The locality consists of broken outcrop and rubble of weakly cleaved, massive, light yellow-grey felsic tuff, aphanitic to sand-size and aphyric, of the Lower Birch Island Member, in a partly slumped half-metre wall along a roadside ditch on the south (uphill) side of the road. The fossil collection (GSC loc. O-108123) was examined by Neuman who identified in decreasing order of abundance: Schedophyla potteri Neuman, 1971; Productorthis mainensis Neuman, 1964; Rugostrophia sylvestris Neuman, 1971; and small numbers of specimens that resemble Tritoechia and Paralenorthis but cannot be confidently identified (Neuman, written communication to Poole, 1998). He commented further: "Most of the Schedophyla specimens are as much as twice the size of those from the Middle Hayden Brook locality, and their imbricated shells pave bedding surfaces of some of the blocks in the sample to the virtual exclusion of other forms. All specimens appear to be disarticulated, and ventral valves are far more common than dorsals, perhaps a 10:1 ratio. [This situation] appears to be the result of sorting and distribution by water currents. Many Productorthis specimens from other layers are articulated, an indication of weaker currents. The few large Rugostrophia shells are all disarticulated.

"Beyond New Brunswick, Schedophyla has also been identified in Arenig/Llanvirn-age assemblages in southern China (Rong Jia$\mathrm{Yu}$, Nanjing Institute of Paleontology and Geology, written communication, 1987).”

\section{Turnbull Mountain locality}

The Turnbull Mountain locality was found by Poole during 1997 shortly after the North Taxis Road locality (Fig. 3). It is located $1.3 \mathrm{~km}$ south of the North Taxis Road locality, along an old logging road on the eastern side of Turnbull Mountain, about $0.8 \mathrm{~km}$ at $104^{\circ}$ azimuth from the top of Turnbull Mountain (zone $1966152 \mathrm{E} 514598 \mathrm{~N} \mathrm{FB}$ ). The locality consists of rubble exposed where road building had removed the organic layer and some of the thin till layer many years previously. The fossils occur in massive, aphyric felsic tuff rubble, light greenish grey to creamy grey, of the Lower Birch Island Member, almost identical lithologically to the North Taxis Road locality. The fossiliferous layer, about 3 $\mathrm{cm}$ thick, is cut by a weak cleavage about 45 degrees to the layer and, given that the cleavage in nearby bedrock is steep, the fossil layer dips moderately. Hand trenching revealed that some of the rubble lies above barren glacial till 20 to $30 \mathrm{~cm}$ below the surface. Evidently, the "rubble" has been moved a short distance into place above till by glacial ice. As interpreted from rubble, the one metre of tuff is faulted on the southeast against Caradocian dark grey slate-chert and is underlain by nearly 2 metres of weakly cleaved, massive and weakly laminated slate, light green-grey to light grey, to the end of the trench in till. Most of the brachiopods were collected from the tuff layer and only a few fragmentary brachiopods from the underlying slate. The first collection (GSC loc. O-108124) was examined by Neuman who identified aff. Eostrophomena sp. of McKerrow and Cocks $(1977,1986)$ (Neuman, written communication to Poole, 1998). He commented: “These specimens are plainly conspecific with the specimens from the Davidsville Group at Gander Lake, Newfoundland (Blackwood 1982) that remain in "open nomenclature" despite having been identified as a 'Celtic Province' orthid and illustrated twice by McKerrow and Cocks $(1977,1986)$. Specimens that would permit confident taxonomic analysis are not yet in hand". Neuman and Poole recollected the locality in 1998 (GSC loc. O-108196) and later that year Poole hand-trenched the locality for stratigraphy. More from the same layer were sent to Neuman (GSC loc. O-108196) as well as a few fragmentary brachiopods from the underlying slate (GSC loc. O108197). Neuman reported (oral communication to Poole, 1998) that he identified Eostrophomena and bryozoa in the collections as well as two specimens of a large, unknown brachiopod, that may be Ukoa sp., poorly described by Öpik (1932). During 1999, Neuman, W.H. Forbes and Poole hand-trenched the Turnbull Mountain locality with renewed diligence in search of Ukoa? (GSC loc. O-108209). From this collection, Neuman identified Monorthis sp. and many specimens of Ukoa?, both dorsal and ventral valves (Neuman, written communication to Poole, 1999).

\section{Long Hill locality}

The third locality was found in 1998 by Neuman when Poole led him and Fyffe to promising aphyric felsic tuff of the Lower Birch Island Member lying above a quartzite conglomerate. The tuff seems to be identical to that in the two above localities. The locality occurs on an old logging road that runs straight northwesterly up a knob lying next to and southeast of Otter Slide Mountain (Fig. 3). The locality is located $0.45 \mathrm{~km}$ at $294^{\circ}$ azimuth from the junction of the main Napadogan haulage road and the Upper Hayden road leading to the Mine road (zone 19 66182E $514892 \mathrm{~N} \mathrm{FB}$ ). Neuman found a single mould of a small, coarsely 
ribbed brachiopod in a loose piece of tuff that he intentionally left at the locality.

\section{Headwaters of Middle Hayden Brook locality}

The last locality was found in 2000 by Poole on an old logging road $0.57 \mathrm{~km}$ at $185^{\circ}$ azimuth from a crossroad junction of the Mine road and the Slate Island road/Lower Hayden road (Fig. 4; zone $1966532 \mathrm{E} 515287 \mathrm{~N} \mathrm{FB})$. Fragments of brachiopods were found scattered along 11 metres of the road in loose pieces of quartzose sandstone, slate and some granule conglomerate. The fossiliferous sandstone appears to be less than a few metres stratigraphically below crystal tuff. Neuman determined that the collection (GSC loc. O-108216) contains fragments of brachiopods and that none could be identified (oral communication to Poole, 2000).

\section{Current identifications}

Only four of the seven brachiopod localities in the Napadogan area have yielded confidently-identifiable brachiopods. Brachiopods from the other three localities (Lower Birch Island, Long Hill and Headwaters of Middle Hayden Brook) on reconsideration, are either too deformed or too fragmentary, but they are consistent with the identifications of the four. The loss of calcitic details of the brachiopods in weathered specimens prohibits identification at the species level. Generic names of brachiopods are arranged alphabetically in Table 1 by host formation and enclosing lithology.

Dolerorthis sp. replaces the name Munhella of Neuman (type species M. cummingi, 1968) following Williams and Harper (2000, p.740) in their finding that the latter generic name is an invalid junior synonym.

Monorthis cf. M. typis Bates, 1968. The type species of the genus, M. typis Bates, was based on poorly preserved specimens from coarse-grained sandstone of probable late Arenig age from the Treiorwerth Formation of Anglesey in northwestern Wales, the only occurrence known at that time. The genus, as M. cf. M. menapiae (Davidson), was later reported in carbonate rocks of the San Juan Limestone of the Precordillera in northwestern Argentina (Herrera and Benedetto 1991; Benedetto 2001b). Well-preserved congeners from the volcanic-rich Suri Formation of the Famatina Range in northwestern Argentina (Benedetto 1994) provide information that confirms this identification. Poorly preserved, deformed specimens that may belong to this genus occur in the Davidsville Group of Newfoundland, identified as "aff. Eostrophomena sp." by McKerrow and Cocks (1986). See Hatcher (1990, p. 87) for a photograph of a bedding surface of deformed specimens from the Davidsville Group near Gander, Newfoundland.

"Paralenorthis?" Reassignment of coarse-ribbed shells formerly assigned to Orthambonites (Neuman 1968) follows Jaanusson and Bassett (1993) in their use of the name for specimens from the Shin Brook Formation of Maine. In the absence of the features that permit their discrimination from similarly ornamented shells, "Paralenorthis" is used here for medium to strongly costate brachiopods, formerly referred to as Orthambonites. Many of the characters that permit their recognition are not preserved in specimens from these localities, but the characteristic features that permit discrimination of the genus can be seen in some specimens from the Shin Brook Formation(Jaanusson and Bassett 1993).

Productorthis has been identified at most of these localities from external moulds that preserve its characteristic ornament of imbricated growth lamellae and other features. It has been identified in the Treiorwerth Formation of Wales, and in other Celtic assemblages such as the Shin Brook Formation of Maine and, in Newfoundland, the Summerford Group of New World Island (Neuman 1976) and the Indian Bay Formation (Wonderley and Neuman 1984).

Rugostrophia is distinctive and quite abundant in outcrop on Middle Hayden Brook, the source of the type specimen of the species (R. sylvestris) and the genus that was erected to contain it. The genus is also present in the Summerford Group of Newfoundland (Neuman 1976), in the Treiorwerth Formation of Wales (Neuman and Bates 1978) and in volcaniclastic rocks of western Puna in northwestern Argentina (Benedetto 2001a).

Schedophyla is the most common fossil in the North Taxis Road locality, particularly where moulds of its shells together with smaller numbers of ramose and encrusting bryozoans pave bedding surfaces. Reported also from northwestern China (Xu and Liu 1984, cited by Cocks and Rong 1989).

Skenidioides is a small shell collected at the Middle Hayden Brook locality that occurs in Celtic assemblages in the Treiorwerth and Nantannog formations of Anglesey (Bates 1968) and in volcaniclastic rocks of the Suri Formation in northwestern Argentina (Benedetto 1994).

Tritoechia is known from only one specimen from all of these localities, the Tetagouche River locality, but it is common in Celtic assemblages elsewhere and in carbonate rocks of the Laurentian platform. The one specimen here is unique for its preservation as an external mould of the two conjoined valves, that, when collected, was filled with large crystals of calcite that were dissolved in the laboratory.

"Ukoa" sp. indet. refers to the nearly forty specimens from the Turnbull Mountain locality of a large dorsibiconvex, fineribbed shell, many of whose characters are not preserved (Fig. 11). The name itself is used with uncertainty because the original description (Öpik 1932) neither mentioned nor illustrated features of the cardinalia that are essential for its classification (see Cocks and Rong 1989, p. 150). We are seeking assistance of colleagues to solve this problem.

\section{DISCUSSION AND CONCLUSIONS}

The relatively thin Arenig strata of Napadogan area vary markedly from southeast to northwest: argillite in the south- 
Table 1. Brachiopods from late Arenig strata of the Miramichi terrane, New Brunswick.

\begin{tabular}{|c|c|c|c|c|c|}
\hline \multirow[b]{4}{*}{ Genera $\backslash$ Host rock } & \multicolumn{4}{|c|}{ Turnbull Mountain Formation } & \multirow{2}{*}{\begin{tabular}{|c} 
Nepisiguit Falls \\
Formation
\end{tabular}} \\
\hline & \multicolumn{4}{|c|}{ Lower Birch Island Member } & \\
\hline & $\begin{array}{l}\text { Middle Hayden } \\
\text { Brook locality }\end{array}$ & $\begin{array}{c}\text { Rocky Brook } \\
\text { locality }\end{array}$ & $\begin{array}{l}\text { North Taxis } \\
\text { Road locality }\end{array}$ & $\begin{array}{c}\text { Turnbull } \\
\text { Mountain } \\
\text { locality }\end{array}$ & Tetagouche River locality \\
\hline & argillite & argillite & felsic tuff & felsic tuff & siltstone \\
\hline Dolerorthis & - & $\mathrm{x}$ & - & - & - \\
\hline Monorthis & - & $\mathrm{x}$ & - & $\mathrm{x}$ & - \\
\hline "Paralenorthis" & - & - & $\mathrm{x}$ & $\mathrm{x}$ & $\mathrm{x}$ \\
\hline Productorthis & $\mathrm{x}$ & - & $\mathrm{x}$ & $\mathrm{x}$ & - \\
\hline Rugostrophia & $\mathrm{X}$ & - & - & - & $\mathrm{x}$ \\
\hline Schedophyla & $\mathrm{x}$ & - & $\mathrm{X}$ & - & - \\
\hline Skenidioides & $\mathrm{x}$ & - & - & - & - \\
\hline Tritoechia & - & - & ? & - & $\mathrm{x}$ \\
\hline "Ukoa" & - & - & - & $\mathrm{X}$ & - \\
\hline
\end{tabular}

Abundance indicated by: $\mathrm{X}$ (bold face $)=$ very abundant, coquinoid shell beds in places; $\mathrm{x}=$ moderate abundance to rare; - = not observed.

east (Rocky Brook and Middle Hayden fossil localities) through siltstone with thin felsic tuff interbeds (Lower Birch Island fossil locality) to thicker felsic tuff and underlying minor argillite and sandstone in the northwest (Otter Slide and Burnt Hill belts). The sedimentary strata in all these localities lack volcanic detritus. The volcanic rocks are tuffs (except for a local basalt flow on Middle Hayden and Lower Hayden brooks) and probably were derived from volcanism farther to the northwest beyond the limits of the Napadogan area. The exposures of Arenig strata are parts of probable thrusts from the northwest juxtaposed from their original depositional sites.

The location of source areas and the mode of deposition of the sedimentary strata are conjectural. The Upper Buttermilk quartzite conglomerate in the northwestern Napadogan area was probably derived, not from a relatively non-rifted Gander margin to the southeast of the Napadogan area, but from a hypothetical, subaerial, short-lived, rift-related uplift, herein named the Napadogan uplift, located during the Arenig between strata of the Otter Slide-Burnt Hill belts and of the Lower Hayden belt. The quartz-sandstone pebble and cobble gravel was derived from the light grey facies in the upper beds of the Miramichi Group, was probably first deposited on local submarine fans off vigorous streams, and later flowed as mass submarine slumps northwestward down submarine canyons to come to rest as lenses of gravel in water depths where oxic, light grey and anoxic, dark grey Miramichi facies were interlayered. Erosion was deep enough to reach consolidated sandstone but not deep enough to reach quartz veins and penetratively deformed sandstone, if any then existed, nor to reach basement rocks beneath the Miramichi strata. Slumping was triggered probably by earthquakes caused by faulting and volcanism. The conglomerate of the Tetagouche Group and Shin Brook Formation may point to a zone of nearby rift faults and thus, a zone of higher probability of the occurrence of volcanogenic massive sulphide deposits if such deposits in a back-arc setting are indeed spatially and genetically related to rift faults and volcanism. No such faults have been recognized in the Miramichi and Lunksoos terranes, because they would probably be sites of younger faults, thus obscuring their earlier history.

The much different, polymictic pebble to boulder conglomerate at the base of the Shin Pond Formation in the Island Falls quadrangle and of the Vallée Lourdes Member along the Tetagouche River near Vallée Lourdes requires a mixed quartzite and volcanic source area. We suspect the structurally overlying, obducted Penobscot Arc rocks, but we must await geochemical and isotopic studies by others for confirmation or otherwise of this speculation.

Within the Napadogan area, felsic tuffs are thicker and coarser textured in the northwest and thin southeastward to intercalated fine-grained tuff less than a few centimetres thick in siltstone in the "middle" Napadogan area (Lower Birch Island locality) and then to zero in southeastern Napadogan. Celtic brachiopods and associated fauna within tuffs and associated strata probably lived along the flanks of the Napadogan uplift, became smothered by periodic, airborne volcanic ash falls, and quickly reoccupied the buried sites. The ash settled into relatively deep water at or just below wave base, and was not reworked by water currents. Soon after primary deposition and before consolidation by diagenesis, the ash may have undergone minor slumping. The volcanic source lay somewhere to the northwest of the Napadogan area. The Lunksoos area by virtue of its much thicker and coarser volcanic 


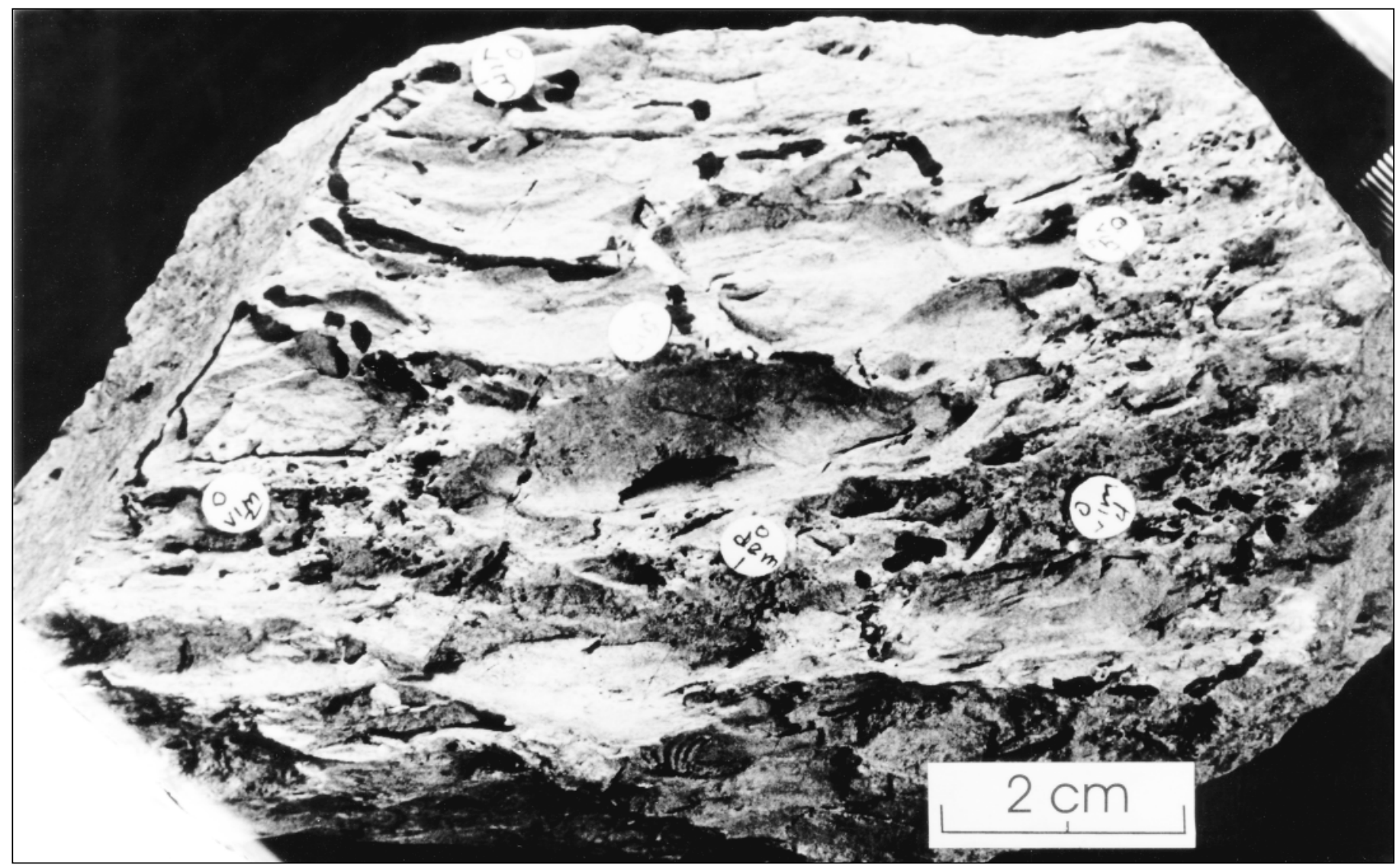

FIG. 11 "Ukoa?" sp. indet. on a bedding surface of silty tuff of the Lower Birch Island Member of the Turnbull Mountain Formation, Napadogan area. Block, GSC Photo 94368, from a hand excavation at the Turnbull Mountain fossil locality, GSC loc. O-108209. The calcareous shells have been dissolved during weathering. The surface of the opposite side of the block consists of a shell bed exclusively of the brachiopod Monorthis. Five of the six Ukoa? specimens shown here are internal moulds of nearly flat ventral valves, whereas a highly convex dorsal valve is in the lower middle part of the view, seen as the deeply concave surface that has very fine (nearly obliterated) radial striations, features that are consistent with those of Ukoa as this genus is currently understood (Cocks and Rong 1989). Turnbull Mountain, old logging road, about $0.8 \mathrm{~km}$ at $104^{\circ}$ azimuth from the mountain top. Smithsonian Institution photograph by V.E. Krantz. GSC Photo 2002-422

assemblage was probably closer to a hypothetical belt of volcanism lying between the general areas of Lunksoos and Bathurst during the Arenig. The core of the hypothetical belt in its post-thrusting location may be marked by early Ordovician granitic bodies extending from the Rockabema granite in the Lunksoos area to several in the central and northeastern Miramichi Highlands.

The fine-grained strata with Celtic brachiopods of the Lower Hayden belt were probably derived from recycled Miramichi strata on the Napadogan uplift to the northwest. They are conformable with the underlying Miramichi Group strata, contain detrital muscovite like the Miramichi Group, and lack volcanic detritus. They were probably deposited in relatively deep water, below wave base, between the Napadogan uplift and the southeastern source of Miramichi strata on the Gander margin.

The few genera of brachiopods of late Arenig age from the Miramichi and Lunksoos anticlinoria are part of the Celtic biogeographic assemblages typical of cool waters in high southern latitudes in contrast to the coeval Toquima-Table Head assemblage typical of warm waters in low southern latitudes (Williams 1973; Neuman 1984). These distinctive assemblages together with the paleomagnetic signatures of relevant rocks permitted the paleogeographic reconstruction of the Iapetus paleo-ocean (Harper $e t$ al. 1996), but do not incorporate information beyond the Iapetus basin such as northwestern China (Xu and Liu 1984) and recently published information from northwestern Argentina (Benedetto 1994, 2001a). Both of these latter areas have brachiopods that are remarkably similar to those of the Iapetan Celtic assemblages. The terrane in northwestern Argentina is believed to be part of a small Laurentian fragment that rifted away during the Early to Middle Ordovician from the Southern Appalachian margin and accreted to Gondwana by the Late Ordovician (Benedetto 2001b).

Localities of these Celtic brachiopods are rare along the Appalachian-Caledonian belt: many localities in the Shin Brook felsic volcanic rocks of the Lunksoos area were first discovered in the northern Appalachians (Neuman 1964), seven localities in the Napadogan area of the central Miramichi Highlands (Fig. 2), one locality along the Tetagouche River in the Bathurst area of northeastern Miramichi Highlands (Fig. 1; Fyffe et al. 1997), several localities in Newfoundland (Wonderley and Neuman 1984; Boyce and Williams 1995; Williams, S.H. et al. 1995), but nowhere in the 
central and southern Appalachians. In Europe, Celtic brachiopods have been found in eastern and southeastern Ireland, in Anglesey (Wales), and in Norway.

We assume that all brachiopods from the Lower Birch Island and Vallée Lourdes members and Shin Brook Formation of the Miramichi and Lunksoos terranes are of the same age from a paleontological perspective. The low diversity of all localities and the poor preservation of fossils in the Miramichi Highlands make impossible the identification of same-age localities and distinguishing those that differ enough to suggest a different age.

The paleontological age of the brachiopods themselves has been interpreted conservatively as late Arenig-early Llanvirn with a strong emphasis on the late Arenig. These Celtic assemblage brachiopods in the Miramichi and Lunksoos terranes can be tied only loosely to strata whose age is known from other fossils. Conodonts from the Middle Hayden Brook locality were interpreted as "may range from early Middle Arenig to earliest Llanvirn" (Nowlan 1981), thus supporting the earlier interpretation of Neuman but not constraining it. In the Bathurst area, conodonts from limestone and siltstone, from 20 to $25 \mathrm{~m}$ above the basal conglomerate and roughly equivalent to the calcareous siltstone carrying brachiopods a few kilometres to the west (Fyffe et al. 1997) yielded only two poorly preserved conodont elements of middle Arenig to Llanvirn age (Nowlan 1981). In the Napadogan area, a unit of manganiferous slate-chert overlying the Turnbull Mountain Formation is barren of fossils except for one exposure of dark grey slate-chert, on Turnbull Mountain, where D.V. Venugopal in 1986 found poorly preserved graptolites. John Riva determined that they were Llanvirnian (written communication to Poole 2001). However, the calcarenite samples from the Lower Birch Island locality collected during 2002 have yielded late Arenig conodonts to G.S. Nowlan (GSC internal report 004-GSN2003). Paleontologically, the Celtic brachiopods and associated conodonts of the Napadogan area are late Arenig.

Supporting this age are U-Pb zircon ages of ca. 471 and $469 \mathrm{Ma}$ from the lower and upper levels of the overlying quartz-feldspar crystal tuff in the northeastern Miramichi Highlands. They are middle to late Arenig (Sullivan and van Staal 1996), if the Arenig lasted from 480 to $465 \mathrm{Ma}$ (McKerrow and van Staal 2000). Thus, the minimum age of the Lower Birch Island and Vallée Lourdes members and probably Shin Brook Formation is late Arenig.

Miramichi-Grand Pitch strata must be looked to for an estimate of the maximum age of the brachiopod-bearing strata. The Grand Pitch is barren of fossils but for the trace fossil Oldhamia, suggestive of a Cambrian age (Neuman 1962) and more recently shown to range from late Precambrian to Middle Cambrian (Hofmann and Cecile 1981). The Baskahegan Lake Formation in New Brunswick yielded ichnotaxa suggestive of an early Ordovician age and is overlain by the Bright Eye Brook Formation of black slate that has yielded late Tremadoc to earliest Arenig graptolites in two localities $9 \mathrm{~km}$ apart (Bailey 1901; Fyffe et al. 1983; Pickerill and Fyffe 1999). Both formations are believed to be equivalent to parts of the Miramichi Group and Grand Pitch Formation, and the Bright Eye Brook Formation is presumed to correlate lithologically with at least part of the black slate-rich uppermost part of the Miramichi-Grand Pitch strata.
The Miramichi Group in the Napadogan area has not yielded fossils or volcanic rocks, but the uppermost unit, the Patrick Brook Formation in the northeastern Miramichi Highlands, has a local, thin rhyolite near the top that has yielded a U-Pb zircon crystallization age of $479 \pm 6 \mathrm{Ma}$ (McNicoll et al. 2002), i.e. some time between the middle Tremadoc and middle Arenig when the error range is considered. This age brackets the graptolite ages of the Bright Eye Brook Formation black slate.

If these postulated regional correlations are correct, then the Lower Birch Island and Vallée Lourdes members and the Shin Brook Formation must be no older than middle Arenig. Middle to late Arenig seems to be the best estimate at present of the ages of these sequences and brachiopods. This estimate is supported by fossils and stratigraphy of the Treiorwerth Formation in northwestern Wales (Fortey et al. 2000).

One feature common to many Arenig fossil localities in the Miramichi Highlands is the low diversity of brachiopods within the collections. For example, one collection may be dominated by one brachiopod species and only a few kilometres along strike, a different brachiopod species dominates. And in one of our localities, a densely populated shell bed carrying one brachiopod species is separated by a few centimetres of sandy tuff from another shell bed dominated by another brachiopod species (see Fig. 11 caption). Admittedly, the Napadogan fossiliferous beds are thin and may not characterize diversity properly. Nevertheless, we suspect that such low diversity in the Miramichi collections is the result of the rapid colonization response to opportunities for expansion by individual brachiopod species along the outer shelves bordering rift-uplifts and volcanic islands in a non-uniform, rapidly-changing environment of sedimentation, volcanism and burial by ash in relatively deep water with relatively narrow uplifts and subsidence along the rift zone during the development of the back-arc basin. In such a scenario, environments favouring brachiopod colonization (e.g., bottom character, currents, salinity, oxygen content, water temperature, nutrients, no competitors or predators) were created from an unpopulated environment. A shell bed, so well developed in the Shin Brook Formation and to a minor extent in the northwestern Napadogan area, probably resulted when a successful brachiopod species colonized new surfaces on a fresh volcanic ash layer during a period of volcanic quiescence in a nutrient-rich environment. By contrast, the Celtic Arenig fossil localities of the Summerford Group in north-central Newfoundland are highly diverse. The Summerford volcanic rocks are tholeiitic and alkalic basalts, and are believed to have been formed as seamounts on an ocean floor (Jacobi and Wasowski 1985). Associated sedimentary rocks are carbonate, greywacke and mudstone. The tectonic environment is unlike that of the Napadogan-Lunksoos areas.

The Napadogan area during the Arenig seems to have been on the fringe of volcanism and sub-volcanic plutons, and by extension, of intense rifting and uplift-subsidence. We suggest the Napadogan rocks lay outside of, and to the southeast of, most of the zone of rifting, etc. characteristic of the Lunksoos area and northeastern Miramichi Highlands.

Reconstructions of the distribution of land masses and oceans during the Arenig universally place the Gander margin of the 
Miramichi-Lunksoos area, and parts of Newfoundland and the British Isles, in southern latitudes with cool waters, about Lat. $45^{\circ} \mathrm{S}$ to $60^{\circ} \mathrm{S}$, adjacent to Gondwana (Neuman 1984; Scotese and McKerrow 1991; van Staal et al. 1998). The Laurentian margin is placed in warmer waters in low southern latitudes, about Lat. $20^{\circ} \mathrm{S}$ to $30^{\circ} \mathrm{S}$. The Iapetus Ocean lies between the two and is perhaps 20 to 30 degrees of latitude wide, or about 2000 to $3000 \mathrm{~km}$.

Such a distance is believed to be more than adequate to prevent brachiopod larvae from colonizing the far side of Iapetus. More mature brachiopods, however, could be carried on floating pumice in circulating ocean currents resembling the modern Gulf Stream. Successful long-range colonization requires tolerance for differing environments. The existence of a Celtic paleogeographic assemblage during the Arenig implies evolution in isolation, protected from invading "foreign" brachiopods and predators by an ocean barrier and(or) intolerance of new conditions on arrival. We reiterate Neuman and Harper's (1992) support of the existence of the Celtic assemblage, in spite of Cocks and McKerrow's (1993) reservations.

\section{ACKNOWLEDGEMENTS}

Poole is responsible for the geology presented here, and the author of most of this paper. During field work from 1997 through 2002 he enjoyed the hospitality of Bob and Karen Armstrong of Stanley, Rod and Esther Flowers of Dorn Ridge and Douglas and Priscilla MacDonald of Burtts Corner, for which he is grateful. He thanks the forest rangers of the New Brunswick Department of Natural Resources and Energy in Stanley for their support, and the staff of Minerals and Energy Division in Fredericton, especially Les Fyffe, Rao Irrinki, and Greg Crouse whose long experience with the geology of the Napadogan terrain led to many enjoyable geological discussions. To this list must be added Dick Potter who generously offered information and thoughts on the geology of the Burnt Hill belt. Gary M. Boone of Presque Isle provided a specimen of the quartzite conglomerate from the base of the Shin Brook Formation. Avenor Pulp and Paper Ltd. and currently Bowater Canadian Forest Products Inc., owners of the Freehold, kindly provided free access to the logging road system. Poole thanks the Geological Survey of Canada for support in the office and field since his retirement. Robert Kelly improved the field photographs with his deft techniques, and Amanda Chiprout patiently converted my crudely drawn figures into images digestible and improvable by computer.

Neuman (1971) had collected and described brachiopods from this area, having been led to relevant outcrops by Poole's colleagues who were familiar with his work there. Poole's later work revealed additional occurrences of fossils, which were sent to Neuman in Washington. He joined Poole in New Brunswick to exploit these discoveries in 1998 and with W. H. Forbes of Presque Isle, Maine, in 1999. The results of this work are presented in the paleontology section of this paper which was written by Neuman. Neuman and Forbes kindly led Poole to a few key outcrops in the Lunksoos area in 2000.

Our thanks to John Riva and especially to Cees van Staal, each of whom critically reviewed early drafts and offered many useful comments and follow-up discussion. Thanks also to journal reviewer Adrian Park for his suggestions for improvement. We have special thanks to reviewer Les Fyffe who has followed Poole's work over the years, has visited "our" rocks from time to time, and diligently made many astute and careful suggestions for improving the first draft. This, of course, is not to say that Les agrees with our favoured positions on the geology. Geological Survey of Canada Contribution 2002017.

\section{REFERENCES}

Амі, H.M. 1906. Preliminary list of the fossils collected by Professor L.W. Bailey from various localities in the Province of New Brunswick during 1904. In Appendix to Summary Report of L.W. Bailey. Geological Survey of Canada, Summary Report for 1904, Part A, pp. 289-292.

Anderson, F.D., \& Poole, W.H. 1959. Geology of Woodstock-Fredericton, York, Carleton, Sunbury, and Northumberland counties, New Brunswick. Geological Survey of Canada, Map 37-1959 (1:126 720 with marginal notes).

BAILEY, L.W. 1901. Summary of work in York and Carleton counties, New Brunswick. Geological Survey of Canada, Summary Report for 1900, Part A, pp. 146-151.

BAILEY, L.W. 1906. Fossil occurrences and certain economic minerals in New Brunswick. Geological Survey of Canada, Summary Report for 1904, pp. 278A-292A.

Bailey, L.W., Mathew, G.F., Ells, R.W., Rовв, C., \& McInnes, W. 1886. Map-sheet No. 2 S.W. (Andover Sheet), Province of New Brunswick. Geological Survey of Canada, map $231(1: 253440)$.

Barr, S.M., \& White, C.E. 1996. Contrasts in late Precambrianearly Paleozoic tectonothermal history between Avalon composite terrane sensu stricto and other possible peri-Gondwana terranes in southern New Brunswick and Cape Breton Island, Canada. In Avalonian and Related Peri-Gondwanan Terranes of the Circum-North Atlantic. Edited by R.D. Nance and M.D. Thompson. Geological Society of America Special Paper 304, pp. 95-108.

Bates, D.E.B. 1968. The lower Palaeozoic brachiopod and trilobite faunas of Anglesey. British Museum (Natural History) Bulletin, Geology, 16, pp. 125-199.

Benedetto, J.L. 1994. Braquiópodos ordovícicos (Arenigiano) de la Formación Suri en la región de Chaschuil, Sistema de Famatina, Argentina. Ameghiniana, 31, pp. 221-238.

BENEDETTO, J.L. 2001a. Una fauna de braquiópodos arenigianos (ordovícico temprano) en rocas volcaniclásticas de la Puna occidental de Argentina: implicaciones paleoclimáticas y palogeográficas. Ameghiniana, 38, pp. 131-146.

BENEDETTO, J.L. 2001b. Silicified early Ordovician (Arenig) brachiopods from the San Juan Limestone (Argentine Precordillera). Geologica et Palaeontologica, 35, pp. 11-29.

Berry, H.N., IV, \& Osberg, P.H. 1989. A stratigraphic synthesis of eastern Maine and western New Brunswick. In Studies in Maine Geology, volume 2, Structure and Stratigraphy. Edited 
by R.D. Tucker and R.G. Marvinney. Maine Geological Survey, pp. 1-32.

BLACKWOOD, R.F. 1982. Geology of the Gander Lake (2D/15) and Gander River (2E/2) area. Newfoundland and Labrador Department of Mines and Energy, Mineral Development Division, Report 82-4, 56 p., map scale 1:50,000.

Boone, G.M., \& Boudette, E.L. 1989. Accretion of the Boundary Mountains terrane within the northern Appalachian orthotectonic zone. In Mélanges and Olistostromes of the U.S. Appalachians. Edited by J.W. Horton, Jr. and N. Rast. Geological Society of America, Special Paper 228, pp. 17-42.

Boone, G.M., Doty, D.T., \& Heizler, M.T. 1989. Hurricane Mountain Formation mélange: description and tectonic significance of a Penobscottian accretionary complex. In Studies in Maine Geology, volume 2, Structure and Stratigraphy. Edited by R.D. Tucker and R.G. Marvinney. Maine Geological Survey, pp. 33-83.

Boyce, W.D., \& Williams, S.H. 1995. One and a half centuries of paleontological research: A selective bibliography of Newfoundland and Labrador fossils. Newfoundland Department of Natural Resources, Geological Survey, Report 95-1, pp. 299-321.

Cocks, L.R.M., \& McKerrow, W.S. 1993. A reassessment of the early Ordovician Celtic brachiopod province. Journal of the Geological Society, 150, pp. 1039-1042.

Cocks, L.R.M., \& RoNG, J-Y. 1989. Classification and review of the brachiopod superfamily Plectambonitacea. British Museum of Natural History Bulletin (Geology) 45, pp. 77-163.

Crouse, G.W. 1981a. Geology of parts of Burnthill, Clearwater and McKiel brooks, map-areas K-14, K-15 and K-16. New Brunswick Department of Natural Resources, Mineral Resources, Map Report 81-5, 46 p., three maps (1:25 000).

Crouse, G.W. 1981b. Geology of Napadogan and Miramichi lakes (map-area K-17) and Napadogan, Rocky, McLean and Ryan brooks (map-area K-18) (Part of 21J/07W). New Brunswick Department of Natural Resources, Mineral Resources, Map Report 81-8, 22 p., two maps (1:25 000).

Ekren, E.B., \& Frischinecht, F.C. 1967. Geological-geophysical investigations of bedrock in the Island Falls quadrangle, Aroostook and Penobscot counties, Maine. U.S. Geological Survey, Professional Paper 527, 36 p., two maps (1:62 500).

ELLs, R.W. 1881. Report on the geology of northern New Brunswick, embracing portions of the counties of Restigouche, Gloucester and Northumberland. Geological Survey of Canada, Report of Progress for 1879-80, Part D, pp. 21-47.

Fortey, R.A., Harper, D.A.T., Inham, J.K., Owen, A.W., \& Rushton, A.W.A. 1995. A revision of Ordovician series and stages from the historical type area. Geological Magazine, 132, pp. 15-30.

Fortey, R.A., Harper, D.A.T., Ingham, J.K., OWen, A.W., Parkes, W., Ruston, A.W.A., \& Woodcock, N.H. 2000. A revised correlation of Ordovician rocks in the British Isles. Geological Society, London, Special Report 24, 83 p.

FyfFe, L.R. 1982. Geology of Woodstock (sheet 21J). New Brunswick Department of Natural Resources, Map NR-4 (1:250 000 with marginal notes).
FyFFE, L.R. 2001. Stratigraphy and geochemistry of Ordovician volcanic rocks of the Eel River area, west-central New Brunswick. Atlantic Geology, 37, pp. 81-101.

Fyffe, L.R., \& Fricker, A. 1987. Tectonostratigraphic terrane analysis of New Brunswick. Maritime Sediments and Atlantic Geology, 23, pp. 113-123.

FyfFe, L.R., Forbes, W.H., \& Riva, J. 1983. Graptolites from the Benton area of west-central New Brunswick and their regional significance. Maritime Sediments and Atlantic Geology, 19, pp. 117-125.

FyfFe, L.R., Mccutcheon, S.R., \& Wilson, R.A. 1997. Miramichi-Tetagouche group stratigraphic relationships, Bathurst mining camp, northern New Brunswick. In Current Research 1996. Edited by B.M.W. Carroll. New Brunswick Department of Natural Resources and Energy, Minerals and Energy Division, Mineral Resource Report 97-4, pp. 37-51.

Globensky, Y. 1981. Régions de Lacolle et Saint-Jean (sud). Ministère de l'Énergie et des Ressources du Québec, Rapport géologique - 197, 197 p., deux cartes (1: 63 360).

Harper, D.A.T., MacNiocaill, C., \& Williams, S.H. 1996. The palaeogeography of Early Ordovician Iapetus terranes: an integration of faunal and palaeomagnetic constraints. Palaeogeography, Palaeoclimatology, Palaeoecology, 121, pp. 297-311.

HATCher, R.D., JR. 1990. Structural Geology. Merrill Publishing Company, Columbus, Ohio, $531 \mathrm{p}$.

Herrera, Z.A., \& Benedetto, J.L. 1991. Early Ordovician brachiopod faunas of the Precordillera basin, western Argentina: biostratigraphy and paleobiogeographical affinities. In Brachiopods through Time. Edited by D. I. MacKinnon, D. E. Lee and J. D. Campbell. Proceedings of the International Brachiopod Congress, 2, A.A. Balkema, Rotterdam, pp. 283-301.

Hofmann, H.J., \& Cecile, M.P. 1981. Occurrence of Oldhamia and other trace fossils in Lower Cambrian(?) argillites, Niddery Lake map area, Selwyn Mountains, Yukon Territory. In Current Research, Part A. Geological Survey of Canada, Paper 81-1A, pp. 281-290.

Hubert, C., Lajoie, J., \& LÉonard, M.A. 1970. Deep sea sediments in the Lower Paleozoic Québec Supergroup. In Flysch Sedimentology in North America. Edited by J. Lajoie. Geological Association of Canada, Special Paper Number 7, pp. 103-125.

IrRINKI, R.R. 1980. Geology of Kennedy Lakes - Little Dungarvon and South Renous rivers region (map areas M-13, M-14, M-15 and part of M-16). New Brunswick Department of Natural Resources, Mineral Resources Branch, Map Report 80-2, 39 p., three maps $(1: 25,000)$.

IRRINKI, R.R. 1981. Geology of Rocky, Sisters and Clearwater brooks-Todd Mountain region, map areas L-14, L-15 and L-16, New Brunswick. New Brunswick Department of Natural Resources, Mineral Resources, Map Report 81-7, 30 p., three maps $(1: 25000)$.

JaAnusson, V., \& BAssett, M.G. 1993. Orthambonites and related Ordovician brachiopod genera. Palaeontology, 36, pp. 21-63.

Jacobi, R.D., \& Wasowski, J.J. 1985. Geochemistry and 
plate-tectonic significance of the volcanic rocks of the Summerford Group, north-central Newfoundland. Geology, 13, pp. 126-130.

Johnson, S.C., \& McLeod M.J. 1996. The New River Belt: A unique segment along the western margin of the Avalon composite terrane, southern New Brunswick, Canada. In Avalonian and Related Peri-Gondwanan Terranes of the Circum-North Atlantic. Edited by R.D. Nance and M.D. Thompson. Geological Society of America Special Paper 304, pp. 149-164.

KIDWELL, S.M. 1986. Models for fossil concentrations: paleobiologic implications. Paleobiology, 12, pp. 6-24.

Kidwell, S.M., \& Aigner, T. 1985. Sedimentary dynamics of complex shell beds: implications for ecologic and evolutionary patterns. In Sedimentary and Evolutionary Cycles. Edited by U. Bayer and A. Seilacher. Springer-Verlag, Berlin, pp. 382-395.

Lutes, G. 1981. Geology of Deersdale-Head of Nashwaak River, map area J-17, and upper parts of Nashwaak River-McBean and Sisters brooks, map area J-18. New Brunswick Department of Natural Resources, Mineral Resources, Map Report 81-4, 26 p., two maps (1:25 000).

McKerrow, W.S., \& Cocks, L.R.M. 1977. The location of the Iapetus suture in Newfoundland. Canadian Journal of Earth Sciences, 14, pp. 488-495.

McKerrow, W.S., \& Cocks, L.R.M. 1986. Oceans, island arcs and olistostromes: the use of fossils in distinguishing sutures, terranes and environments around the Iapetus Ocean. Journal of the Geological Society, 143, pp. $185-191$.

McKerrow, W.S., \& van Staal, C.R. 2000. The Palaeozoic time scale reviewed. In Orogenic Processes: Quantification and Modelling in the Variscan Belt. Edited by W. Franke, V. Haak, O. Oncken and D. Tanner. Geological Society, London, Special Publications, 179, pp. 5-8.

McLeod, M.J., Winchester, J.A., \& Ruitenberg, A.A. 1994. Geochemistry of the Annidale Group: Implications for the tectonic setting of Lower Ordovician volcanism in southwestern New Brunswick. Atlantic Geology, 30, pp. 87-95.

McNicoll, V.J., van StaAl, C.R., Lentz, D., \& Stern, R. 2002. Uranium-lead geochronology of Middle River rhyolite: implications for the provenance of basement rocks of the Bathurst mining camp, New Brunswick. In Radiogenic Age and Isotopic Studies: Report 15. Geological Survey of Canada, Current Research 2002-F9, 11 p.

Neuman, R.B. 1962. The Grand Pitch Formation: new name for the Grand Falls Formation (Cambrian?) in northeastern Maine. American Journal of Science, 260, pp. 794-797.

Neuman, R.B. 1964. Fossils in Ordovician tuffs, northeastern Maine. U.S. Geological Survey, Bulletin 1181-E, 38 p., 7 plates.

Neuman, R.B. 1967. Bedrock geology of the Shin Pond and Stacyville quadrangles, Penobscot County, Maine. U.S. Geological Survey, Professional Paper 524-I, 37 p., two maps (1:62 500).

Neuman, R.B. 1968. Paleogeographic implications of Ordovician shelly fossils in the Magog belt of the northern Appalachian region. In Studies of Appalachian Geology: Northern and Maritime. Edited by E-An Zen, W.S. White, J.B. Hadley and J.B.
Thompson, Jr. Interscience Publishers (a division of John Wiley \& Sons), pp. 35-48.

Neuman, R.B. 1971. An early Middle Ordovician brachiopod assemblage from Maine, New Brunswick, and northern Newfoundland. In Paleozoic Perspectives: A Paleontological Tribute to G. Arthur Cooper. Edited by J. T. Dutro, Jr. Smithsonian Contributions to Paleobiology, 3, pp. 113-124.

Neuman, R.B. 1976. Early Ordovician (late Arenig) brachiopods from Virgin Arm, New World Island, Newfoundland. Geological Survey of Canada, Bulletin 261, pp. 11-61.

Neuman, R.B. 1984. Geology and paleobiology of islands in the Ordovician Iapetus Ocean: Review and implications. Geological Society of America, Bulletin, 95, pp. 1188-1201.

Neuman, R.B., \& Bates, D.E.B. 1978. Reassessment of Arenig and Llanvirn age (Early Ordovician) brachiopods from Anglesey, northwest Wales. Palaeontology, 21, pp. 571-613.

Neuman, R.B., \& Harper, D.A.T. 1992. Paleogeographic significance of Arenig-Llanvirn Toquima-Table Head and Celtic brachiopod assemblages. In Global Perspectives on Ordovician Geology. Edited by B.D. Webby and J.R. Laurie. A.A. Balkema, Rotterdam. Proceedings of the International Symposium on the Ordovician System, 6, pp. 241-254.

Norford, B.S., Jackson, D.E., \& Nowlan, G.S. 2002. Ordovician stratigraphy and faunas of the Glenogle Formation, southeastern British Columbia. Geological Survey of Canada Bulletin 569, $84 \mathrm{p}$.

NowLAN, G.S. 1981. Some Ordovician conodont faunules from the Miramichi Anticlinorium, New Brunswick. Geological Survey of Canada, Bulletin 345, 35 p.

Öрıк, A. 1932. Uber die Plectellinen. Acta et commentationes Universitatus Tartuensis (Dorpatensis) A23.3, pp. 3-85.

Pickerill, R.K., \& Fyffe, L.R. 1999. The stratigraphic significance of trace fossils from the Early Paleozoic Baskahegan Lake Formation near Woodstock, west-central New Brunswick. Atlantic Geology, 35, pp. 205-214.

Poole, W.H. 1958. Napadogan, York County, New Brunswick. Geological Survey of Canada, Map 11-1958 (1:63 360 with marginal notes).

PooLe, W.H. 1960. Hayesville and McNamee map area, York, Northumberland and Carleton counties, New Brunswick. Geological Survey of Canada, Paper 60-15, 10 p., two maps (1:63 360).

Poole, W.H. 1963. Geology, Hayesville, New Brunswick. Geological Survey of Canada, Map 6-1963 (1:63 360 with marginal notes).

PotTER, R.R. 1969. The geology of Burnt Hill area and ore controls of the Burnt Hill tungsten deposit. Unpublished Ph.D. thesis, Carleton University, Ottawa, Ontario, 199 p.

Rice, R.J., \& VAN STAAL, C.R. 1992. Sedimentological studies in the Ordovician Miramichi, Tetagouche, and Fournier groups in the Bathurst camp and the Belledune-Elmtree Inlier, northern New Brunswick. In Current Research, Part D. Geological Survey of Canada, Paper 92-1D, pp. 257-264.

Rовв, C. 1870. Report on the geology of northwestern New Brunswick. Geological Survey of Canada, Report of Progress for 1866 to 1869 , pp. 173-209.

Scotese, C.R., \& McKerrow, W.S. 1991. Ordovician plate 
tectonic reconstructions. In Advances in Ordovician Geology. Edited by C.R. Barnes and S.H. Williams. Geological Survey of Canada, Paper 90-9, pp. 271-282.

Skinner, R. 1974. Geology of Tetagouche Lakes, Bathurst and Nepisiguit Falls map-areas, New Brunswick with emphasis on the Tetagouche Group. Geological Survey of Canada, Memoir 371,133 p., three maps $(1: 50,000)$.

Stewart, D.B., Unger, J.D., \& Hutchinson, D.R. 1995. Silurian tectonic history of Penobscot Bay region, Maine. Atlantic Geology, 31, pp. 67-79.

Sullivan, R.W., \& van StaAl, C.R. 1996. Preliminary chronostratigraphy of the Tetagouche and Fournier groups in northern New Brunswick. In Radiogenic Age and Isotopic Studies: Report 9. Geological Survey of Canada, Current Research 1995-F, pp. 43-56.

van Staal, C.R. 1994. Brunswick subduction complex in the Canadian Appalachians: record of the Late Ordovician to Late Silurian collision between Laurentia and the Gander margin of Avalon. Tectonics, 13, pp. 946-962.

van Staal, C.R., \& Fyffe, L.R. 1991. Dunnage and Gander zones, New Brunswick: Canadian Appalachian Region. New Brunswick Department of Natural Resources and Energy, Mineral Resources, Geoscience Report 91-2, 39 p.

van Staal, C.R., \& Fyffe, L.R. 1995a. Dunnage Zone-New Brunswick. In Chapter 3 of Geology of the AppalachianCaledonian Orogen in Canada and Greenland. Edited by $\mathrm{H}$. Williams. Geological Survey of Canada, Geology of Canada, Volume 6, pp. 166-178 (also Geological Society of America, The Geology of North America, Volume F-1).

van Staal, C.R., \& Fyffe, L.R. 1995b. Gander Zone-New Brunswick. In Chapter 3 of Geology of the AppalachianCaledonian Orogen in Canada and Greenland. Edited by $\mathrm{H}$. Williams. Geological Survey of Canada, Geology of Canada, Volume 6, pp. 216-233 (also Geological Society of America, The Geology of North America, Volume F-1).

van StAal, C.R., Winchester, J.R., \& BÉDARd, J.H. 1991. Geochemical variations in Middle Ordovician volcanic rocks of the northern Miramichi Highlands and their tectonic significance. Canadian Journal of Earth Sciences, 28, pp. 1031-1049.

van StaAl, C.R., FyfFe, L.R., Langton, J.P., \& McCutcheon, S.R. 1992. The Ordovician Tetagouche Group, Bathurst Camp, northern New Brunswick, Canada: history, tectonic setting, and distribution of massive-sulfide deposits. Exploration and Mining Geology, 1, pp. 93-103.

van Staal, C.R., Sullivan, R.W., \& Whalen, J.B. 1996. Provenance and tectonic history of the Gander Zone in the Caledonian/Appalachian orogen: implications for the origin and assembly of Avalon. In Avalonian and Related Peri-Gondwanan Terranes of the Circum-North Atlantic. Edited by R.D. Nance and M.D. Thompson. Geological Society of America Special Paper 304, pp. 347-367.

van Staal, C.R., Dewey, J.F., Mac Niocaill, C., \& McKerRow, W.S. 1998. The Cambrian-Silurian tectonic evolution of the northern Appalachians and British Caledonides: history of a complex, west and southwest Pacific-type segment of Iapetus. In Lyell: the Past is the Key to the Present. Edited by D.J.
Blundell and A.C. Scott. Geological Society, London, Special Publications, 143, pp. 199-242.

van StaAl, C.R., Barr, S.M., Fyffe, L.R., McNicoll, V., Pollock, J.C., Reusch, D.N., Thomas, M., ValverdeVacquero, P., \& Whalen, J. 2002a. Ganderia - an important peri-Gondwanan terrane in the northern Appalachians. Abstract. Geological Society of America, Northeastern Section, meeting, Springfield, Massachusetts, March 25-27, 2002.

van StaAl, C.R., Wilson, R.A., Rogers, N., Fyffe, L.R., Gower, S.J., Langton, J.P., McCutcheon, S.R., \& Walker, J.A. 2002b. Geology, Bathurst Mining Camp and surrounding areas, New Brunswick. Geological Survey of Canada, Open File 4182, scale 1:100 000.

van Staal, C.R., Wilson, R.A., Fyffe, L.R., Langton, J.P., McCutcheon, S.R., Rogers, N., McNicoll, V., \& Ravenhurst, C.E. In press. Geology and tectonic history of the Bathurst Mining Camp and its relationships to coeval rocks in southwestern New Brunswick and adjacent Maine - a synthesis. In Massive Sulphide Deposits of the Bathurst Mining Camp, New Brunswick and northern Maine. Edited by W.D. Goodfellow, S.R. McCutcheon and J.M. Peter. Economic Geology Monograph 11.

WiLLIAMs, A. 1973. Distribution of brachiopod assemblages in relation to Ordovician palaeogeography. In Organisms and Continents through Time. Edited by N.F. Hughes. Palaeontological Association, Special Papers in Palaeontology, 12, pp. 241-269.

Williams, A., \& Harper, D.A.T. 2000. Orthida. In Treatise on Invertebrate Paleontology, Part H, Brachiopoda, Revised, volume 3. Compiled by A. Williams, C.H.C. Brunton, S.J. Carlson, and others. Geological Society of America and the University of Kansas, pp. 714-782.

Williams, S.H., Harper, D.A.T., Neuman, R.B., Boyce, W.D., \& MacNiocaill, C. 1995. Lower Paleozoic fossils from Newfoundland and their importance in understanding the history of the Iapetus Ocean. In Current Perspectives in the Appalachian-Caledonian Orogen. Edited by J.P. Hibbard, C.R. van Staal and P.A. Cawood. Geological Association of Canada, Special Paper 41, pp. 115-126.

Winchester, J.A., \& VAN StaAl, C.R. 1994. The chemistry and tectonic setting of Ordovician volcanic rocks in northern Maine and their relationship to contemporary volcanic rocks in northern New Brunswick. American Journal of Science, 294, pp. 641-662.

Wonderley, P.F., \& Neuman, R.B. 1984. The Indian Bay Formation: early Middle Ordovician volcanogenic rocks in the northern Gander Terrane, Newfoundland, and their regional significance. Canadian Journal of Earth Sciences, 21, pp. 525-532.

XU H-K, \& LIU DI-Y. 1984. Late Early Ordovician brachiopods of southwestern China. Nanjing Institute of Geology and Paleontology, Academia Sinica, Bulletin 8, pp. 147-235.

Editorial responsibility: Ron K. Pickerill 